Mino Yoshihisa (Orcid ID: 0000-0002-9529-2020)

Sukigara Chiho (Orcid ID: 0000-0002-4966-0259)

Wakita Masahide (Orcid ID: 0000-0002-3333-0546)

Yoshikawa Chisato (Orcid ID: 0000-0002-0067-9063)

Kaiser Jan (Orcid ID: 0000-0002-1553-4043)

Kimoto Katsunori (Orcid ID: 0000-0002-1523-6994)

Fujiki Tetsuichi (Orcid ID: 0000-0002-7803-3035)

\title{
Seasonal and interannual variations in nitrogen availability and particle export in the northwestern North Pacific subtropical gyre
}

\section{Y. Mino ${ }^{1 *}$, C. Sukigara ${ }^{2}$, M. C. Honda ${ }^{3}$, H. Kawakami ${ }^{3}$, M. Wakita ${ }^{3}$, K. Sasaoka ${ }^{3}$, C.} Yoshikawa $^{3}$, O. Abe ${ }^{4}$, J. Kaiser ${ }^{5}$, K. Kimoto ${ }^{3}$, M. Kitamura ${ }^{3}$, T. Fujiki ${ }^{3}$, K. Matsumoto ${ }^{3}$, T. Saino

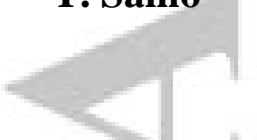

${ }^{1}$ Institute for Space-Earth Environmental Research, Nagoya University, Nagoya, Japan.

2 Tokyo University of Marine Science and Technology, Tokyo, Japan.

${ }^{3}$ Japan Agency for Marine-Earth Science and Technology, Yokosuka, Japan.

${ }^{4}$ Graduate School of Environmental Studies, Nagoya University, Nagoya, Japan.

${ }^{5}$ Centre for Ocean and Atmospheric Sciences, School of Environmental Sciences, University of East Anglia, Norwich, UK.

Corresponding author: Yoshihisa Mino (kuro@ hyarc.nagoya-u.ac.jp)

\section{Key Points:}

- Changes in nitrogen availability in the western NPSG were revealed by delta nitrogen-15 time-series of settling particles at $200 \mathrm{~m}$ during 2010-14.

- Reduced delta nitrogen-15 every winter corresponded to convective nitrate supply that triggered algal blooms and enhanced downward $\mathrm{CaCO}_{3}$ transport.

- Stronger convective mixing in 2011-12 than 2013-14 enhanced particle flux with a reduced organic carbon to inorganic carbon export ratio.

This article has been accepted for publication and undergone full peer review but has not been through the copyediting, typesetting, pagination and proofreading process which may lead to differences between this version and the Version of Record. Please cite this article as doi: 10.1029/2019JC015600 


\begin{abstract}
Time-series of particulate nitrogen isotope delta $\left(\mathrm{PN}-\delta^{15} \mathrm{~N}\right)$ and flux of trapped particles at $200 \mathrm{~m}$ were determined in the northwestern North Pacific subtropical gyre (NPSG) between 2010 and 2014 in order to examine temporal variations in mixed layer nitrate availability and downward particle export. Lower $\mathrm{PN}-\delta^{15} \mathrm{~N}(<4 \%$ ) seen every winter corresponded to convective nitrate supply triggering phytoplankton blooms. Greater particle fluxes were associated with higher $\mathrm{CaCO}_{3}$ concentrations (mass fraction $>50 \%$ ), implying that new nitrogen supply stimulated predominantly coccolithophore growth and downward transport of coccoliths. Even in the stratified summer of 2011, a $\delta^{15} \mathrm{~N}$ drop associated with a spike in particulate flux was found and was attributed to the uplift of nitrate-rich deep waters due to a mesoscale cyclonic eddy passing the mooring station. Total nitrate input sustains $86-93 \%$ of annual new production in this region while nitrogen fixation accounts for the rest. Trapped particles also showed that the winter $\delta^{15} \mathrm{~N}$ decrease appeared earlier in the 2011-12 blooms than those in 2013-14, coinciding with $8 \%$ higher $\mathrm{CaCO}_{3}$ concentrations and a $40 \%$ lower particulate organic carbon to inorganic carbon export ratio, $R$ (POC:PIC). This reflected stronger convective mixing and hence larger nutrient supply in 2011-12, caused by larger ocean heat loss related to winter monsoon intensity. Such interannual change of winter $R\left(\mathrm{POC}: \mathrm{PIC}\right.$ ) can affect $\mathrm{CO}_{2}$ uptake rate in the northwestern NPSG where anthropogenic $\mathrm{CO}_{2}$ accumulates in subtropical mode waters.
\end{abstract}

\title{
Plain Language Summary
}

Nutrient availability limits primary productivity in the low and mid-latitude oceans. This constrains the export of sinking biogenic particles, which removes carbon from the atmosphere, the so-called biological pump. We examined temporal variations in nitrogen availability and particle export in the northwestern North Pacific subtropical gyre (NPSG), using sediment trap time-series observations at $200 \mathrm{~m}$ depth between 2010 and 14 . We found that the nitrogen isotope ratio $\left({ }^{15} \mathrm{~N} /{ }^{14} \mathrm{~N}\right)$ of trapped particles varied according to the external input of "new" nitrogen. 86-93\% of "new nitrogen" was nitrate supplied from subsurface waters. Reduced ${ }^{15} \mathrm{~N} /{ }^{14} \mathrm{~N}$ ratios of high particle fluxes every winter indicated that nitrate was mainly supplied via convective mixing, triggering phytoplankton blooms. Interestingly, the magnitude of convective nitrate supply varied from year to year, depending on winter monsoon intensity. This not only controls particle fluxes but also their composition. Stronger mixing in 2011-12 than in 2013-14 enhanced $\mathrm{CaCO}_{3}$ export and hence reduced the organic carbon to inorganic carbon export ratio, $R$ (POC:PIC). Such interannual changes of winter $R$ (POC:PIC) can affect air-sea $\mathrm{CO}_{2}$ fluxes through modulating $\mathrm{CO}_{2}$ partial pressure in the northwestern NPSG.

\section{Introduction}

The subtropical gyres occupy ca. $60 \%$ of the total ocean surface [Longhurst, 1998], and are considered to account for 30-50\% of total organic carbon export from the upper ocean [Emerson et al., 1997; Mouriño-Carballido and Neuer, 2008]. The subtropical gyres are presumed to have expanded and are projected to expand further as a consequence of global warming [Polovina et al., 2008; Zhang et al., 2014]. It is therefore important to understand how subtropical ecosystems and their biological pump respond to changes in the climate system, e.g. enhanced ocean stratification. Unlike in the high-latitude ocean, phytoplankton biomass is generally low in oligotrophic subtropical waters above a deep permanent pycnocline that inhibits upward mixing of deeper nutrient-rich waters. On the other hand, basin scale heterogeneities in chlorophyll concentration, primary productivity, and their seasonalities have been found at different time-series locations in the subtropics, i.e. 
BATS in the eastern North Atlantic [Steinberg et al., 2001], ESTOC in the western North Atlantic [Neuer et al., 2007] and ALOHA in the eastern North Pacific [Karl et al., 1996]. Moreover, mesoscale and submesoscale variations in productivity have been revealed by observations with autonomous platforms (e.g. profiling floats, submersible gliders) as well as satellite images [Nicholson et al., 2008; Riser and Johnson, 2008; Guidi et al., 2012]. These dynamic features imply that the subtropical ecosystem is fueled by "new" nutrient inputs into the euphotic zone on multiple spatio-temporal scales and a variety of processes such as winter convection, mesoscale eddy activity, typhoon/hurricane passages as well as dinitrogen $\left(\mathrm{N}_{2}\right)$ fixation.

In the northwestern North Pacific Subtropical Gyre (NPSG), deep mixed layers ( $>150$ $\mathrm{m}$ ) form in winter south of the Kuroshio Extension, KE (Figure 1) due to an outflow of cold, dry continental air (i.e. winter monsoon) across the warm water. Here, "seasonal" phytoplankton blooms occur from winter to spring [Siswanto et al., 2015; Fujiki et al., 2016] in contrast to the eastern NPSG where a summer increase of surface biomass and diazotroph populations has been found with some regularity [Dore et al., 2008; Karl et al., 2012]. This distinct seasonal bloom implies a greater importance of nitrate $\left(\mathrm{NO}_{3}^{-}\right)$input due to winter convective mixing as new N source in the northwestern part of the NPSG. It has been suggested that mesoscale eddies originate and propagate westward from a "hot spot" of eddy activity along the KE [Qiu and Chen, 2010], possibly driving episodic nutrient supply and enhancing local productivity during stratified periods [Sukigara et al., 2014; Inoue et al., 2016; Honda et al., 2018]. Furthermore, dinitrogen $\left(\mathrm{N}_{2}\right)$ fixation can contribute to new $\mathrm{N}$ supply [Kitajima et al., 2009; Shiozaki et al., 2010]. The relative contributions of these N inputs to annual new production remain unclear owing to a lack of time-series observations in the western NPSG.

The ${ }^{15} \mathrm{~N} /{ }^{14} \mathrm{~N}$ isotope ratio (expressed as $\delta^{15} \mathrm{~N}$ ) of settling particles has been used to reconstruct availability and utilization of nitrogenous nutrients in the upper ocean [Altabet et al., 1991; Altabet and Francois, 1994; Wu et al., 1999; Dore et al., 2002; Lourey et al., 2003; Yoshikawa et al., 2005; Mino et al., 2016; Böttjer et al., 2017]. When nitrate $\left(\mathrm{NO}_{3}{ }^{-}\right)$is the main $\mathrm{N}$ source, phytoplankton assimilate ${ }^{14} \mathrm{NO}_{3}{ }^{-}$preferentially and form particulate nitrogen (PN) with lower $\delta^{15} \mathrm{~N}$ than that of the nitrate initially supplied [Miyake and Wada, 1967]. In a closed system with PN formation proceeding, this isotope fractionation makes the $\delta^{15} \mathrm{~N}$ of the remaining nitrate higher as its concentration decreases. Then, this elevated $\delta^{15} \mathrm{~N}$ signal is imprinted onto the $\mathrm{PN}$ formed subsequently from the remaining nitrate (up to a maximum $\delta^{15} \mathrm{~N}$ value equal to that of the initial nitrate). In short, lower $\mathrm{PN}-\delta^{15} \mathrm{~N}$ indicates relatively high nitrate availability when the PN is formed, and higher $\mathrm{PN}-\delta^{15} \mathrm{~N}$ indicates lower availability. Here we examine $\mathrm{PN}-\delta^{15} \mathrm{~N}$ variations in settling particulate nitrogen at $200 \mathrm{~m}$ during 2010-14 obtained from moored sediment traps (MST) in order to reveal temporal variations in upper ocean $\mathrm{N}$ availability. The MST experiment was conducted under the "K2S1 project" [Honda et al., 2017], which provided, for the first time, biogeochemical timeseries data in the northwestern NPSG (Figure 1). Repeat cruise observations of PN- $\delta^{15} \mathrm{~N}$ of the suspended particle load between 10 and $200 \mathrm{~m}, \delta^{15} \mathrm{~N}$ (SUS), and the settling particle fraction collected by drifting sediment traps at 100-200 m, $\delta^{15} \mathrm{~N}(\mathrm{DST})$, were also used. Based on the relationships between trapped $\mathrm{PN}-\delta^{15} \mathrm{~N}$, particle fluxes and chemical composition (i.e. organic matter and calcium carbonate content), we discuss the implications for the changing carbon cycle in the northwestern NPSG where anthropogenic $\mathrm{CO}_{2}$ accumulates in the mode waters that form in the winter deep mixed layer [Kouketsu et al., 2013]. 


\section{Materials and Methods}

2.1 Hydrographic observation and sample collections

At station $\mathrm{S} 1\left(30^{\circ} \mathrm{N}, 145^{\circ} \mathrm{E}\right.$; Figure 1), we conducted seasonal observations during five scientific cruises: MR10-06 (early November 2010; doi: 10.17596/0001829), MR11-02 (mid-February 2011; doi: 10.17596/0001830), MR11-03 (late April 2011; doi: 10.17596/0001831), MR11-05 Leg2 (late July 2011; doi: 10.17596/0001833), and MR12-02 Leg2 (late June 2012; doi: 10.17596/0001842) on board R/V Mirai, Japan Agency for Marine-Earth Science and Technology (JAMSTEC). All water samples were collected by 12L Niskin-X bottles (General Oceanics) attached to a rosette sampling system equipped with a CTD sensor (911 plus, Sea-Bird Electronics), as well as using a bucket (surface water only). The fluorometer attached to the rosette gave profiles of in situ chlorophyll $a(\mathrm{Chl} a)$ fluorescence, which was calibrated against on board measurements of Chl $a$ concentration in discrete samples. Chl $a$ collected on 25-mm diameter GF/F filters (Whatman) was extracted in $N, N$-dimethylformamide in the dark at $-20^{\circ} \mathrm{C}$ for $24 \mathrm{~h}$ and then measured in a Turner fluorometer (model 10-AU, Turner Designs). Nutrient concentrations were measured with a continuous flow analyzer (QuAAtro 2-HR system, BL-Tech), for which the detection limit of nitrate was estimated as $0.03 \mu \mathrm{mol} \mathrm{kg}{ }^{-1}$. For $\delta^{15} \mathrm{~N}$ of suspended particles, 20 to $80 \mathrm{~L}$ of seawater were filtered through precombusted $\left(450{ }^{\circ} \mathrm{C}\right.$ for $5 \mathrm{~h}$ ) GF/F filters (47-mm diameter). The filters were stored at $-20{ }^{\circ} \mathrm{C}$ until isotopic analysis on shore. Water samples of $50 \mathrm{~mL}$ for nitrate $\delta^{15} \mathrm{~N}$ were also taken during cruise MR10-06 and MR12-02, which were kept at -20 ${ }^{\circ} \mathrm{C}$ until analysis. Additional nitrate $\delta^{15} \mathrm{~N}$ samples were collected during cruises in July 2013 (MR13-04) and July 2014 (MR14-04).

\subsection{Collection of settling particles}

In this study, we collected particles exported from the upper $200 \mathrm{~m}$ at $\mathrm{S} 1$ (corresponding to the deepest seasonal mixed layer [Wakita et al., 2016]), by using both short-term drifting sediment traps (DST) and time-series moored sediment traps (MST), to examine fluxes, chemical composition as well as particulate $\delta^{15} \mathrm{~N}$. During all cruises mentioned above, we deployed a DST array with cylindrical collectors for 3 to 4 days, filled with high-salinity filtered seawater (adjusted to $S=39$ ) and positioned at 60,100, 150, and 200 $m$ depths. More details have been described elsewhere [Honda et al., 2015]. Particles settled on the collector bottom were filtered onto pre-weighed Nucleopore filters (Whatman) for measurements of total mass flux and trace elements, and on pre-weighed, pre-combusted GF/F filters (25-mm diameter) for particulate organic carbon and nitrogen (POC, PN) and $\mathrm{PN}-\delta^{15} \mathrm{~N}$.

MST deployments were conducted five times between February 2010 and June 2014, in which conical traps (SMD26S-6000, Nichiyu Giken Kogyo) were deployed at $200 \mathrm{~m}$ by R/V Mirai. Before deployment, the collection cup was filled with seawater-based $10 \%$ buffered formalin as a preservative. The sampling interval was between 6 and 18 days. The trap recoveries took place during cruises of R/V Mirai and R/V Kaiyo (JAMSTEC).

Following trap recovery, samples were stored at $4{ }^{\circ} \mathrm{C}$ until pretreatment (water sieving, swimmer elimination, splitting, filtration, drying, and pulverization) on shore (see details in Honda et al. [2013]).

\subsection{Chemical analyses}

The dry weight of the trapped particles by DST and MST was measured to estimate total mass fluxes. Concentrations of $\mathrm{Al}, \mathrm{Si}$, and $\mathrm{Ca}$ in those particles were measured with an inductively coupled plasma atomic emission spectrometer (Optima 3300DV, Perkin-Elmer) 
at JAMSTEC. POC and PN in the samples were measured after $\mathrm{HCl}$ fumigation for $24 \mathrm{~h}$ with a CHN/O elemental analyzer (Flash2000, Thermo Fisher Scientific). These data were used to estimate the concentrations of organic material (OM), biogenic opal, $\mathrm{CaCO}_{3}$, and lithogenic materials (LM), following Honda et al. [2015]. DST and MST data are available in the "K2S1 database" (https://ebcrpa.jamstec.go.jp/k2s1/en/mst.html).

$\delta^{15} \mathrm{~N}$ values of both suspended and settling particles were measured with an elemental analyzer coupled to a continuous flow isotope-ratio mass spectrometer (EA1110-Delta Plus, Thermo Fisher Scientific) at Nagoya university, calibrated against IAEA-N-1, with the precision better than $0.2 \%$ estimated from repeated measurements of laboratory standards (Amino Standard, SI science). Nitrate $\delta^{15} \mathrm{~N}$ was determined using the denitrifier method following Sigman et al. [2001] and Kaiser et al. [2007]. Samples from MR10-06 were measured at the

University of East Anglia, with IAEA-NO-3 as calibration standard. The accuracy was better than $0.12 \%$, based on comparison between USGS 34 and USGS 35 standards run in the same batch as the IAEA-NO-3 standard used for calibration. Samples from MR12-02, MR1304, and MR14-04 were measured at the University of California, Stable Isotope Facility, with USGS 32, USGS 34, and USGS 35 as calibration standard, in which the intrarun precision was $\pm 0.2 \%$ [Yoshikawa et al., 2015]. Nitrate $\delta^{15} \mathrm{~N}$ data were obtained for samples with nitrate concentration $>2.4 \mu \mathrm{mol} \mathrm{L}-1$. Note that nitrite was not removed from the samples prior to isotopic analysis, but the influence of nitrite on nitrate $\delta^{15} \mathrm{~N}$ values would be $<0.3 \%$ assuming a $\delta^{15} \mathrm{~N}$ difference of $14.4 \%$ between nitrate and nitrite [Buchwald and Casciotti, 2013].

\subsection{Other data}

Daily sea surface temperature (SST) and Chl $a$ were estimated during the trap deployments from 2010 to 2014 by averaging data acquired by the MODIS satellite over an $11 \times 11$ pixel square (approximately $100 \mathrm{~km} \times 100 \mathrm{~km}$ ) centered at S1. Air-sea heat flux averaged over the same area was obtained from a global data set of objectively analyzed airsea fluxes (http://oaflux.whoi.edu).

\section{Results}

3.1 Seasonal variations of hydrography, nitrate and particulate nitrogen concentrations, and their $\delta^{15} \mathrm{~N}$ values in the upper layer

Five cruises between 2010 and 2012 revealed seasonal changes in water density, Chl $a$, and nutrient concentrations, and $\delta^{15} \mathrm{~N}$ of particles in the upper $200 \mathrm{~m}$ at S1 (Figure 2, Table 1). Mixed layer depth (MLD), determined based on a potential density difference of $0.125 \mathrm{~kg}$ $\mathrm{m}^{-3}$ from the near-surface $(10 \mathrm{~m})$ value, reached $200 \mathrm{~m}$ in winter (February 2011) due to winter convective mixing. At that time, nitrate concentrations were above $0.4 \mu \mathrm{mol} \mathrm{L}^{-1}$ in the mixed layer (Figures 2a, b). The MLD shoaled to $49 \mathrm{~m}$ in spring (April 2011), and further to $<20 \mathrm{~m}$ in summer (July 2011, June 2012). Afterwards, it deepened to $55 \mathrm{~m}$ in autumn (November 2010). During these stratified periods in summer and autumn, nitrate was depleted to $<0.1 \mu \mathrm{mol} \mathrm{L}{ }^{-1}$ in the surface water. Below the MLD, nitrate increased to $1-3$ $\mu \mathrm{mol} \mathrm{L} \mathrm{L}^{-1}$ at $100 \mathrm{~m}$ with $\sigma_{\theta}$ (potential density $-1000 \mathrm{~kg} \mathrm{~m}^{-3}$ ) values of $24.8-25.1 \mathrm{~kg} \mathrm{~m}^{-3}$ (Figures 2b, 3a). A maximum Chl $a$ concentration of $0.8 \mathrm{mg} \mathrm{m}^{-3}$ was found in the surface water in winter (Figure 2c). Surface Chl $a$ decreased to $0.4 \mathrm{mg} \mathrm{m}^{-3}$ in spring and to $<0.1 \mathrm{mg}$ $\mathrm{m}^{-3}$ during summer to autumn, whereas high concentrations of $0.4-0.7 \mathrm{mg} \mathrm{m}^{-3}$ appeared in the subsurface layer (deep Chl $a$ maximum: DCM) located at 50-90 m, near the top of the nitracline. The depth of the DCM was $50 \mathrm{~m}$ in spring (April 2011) and deepened to $50-70 \mathrm{~m}$ 
in early summer (June 2012), 70-90 m in mid summer (July 2011) and autumn (October 2010). Depth-integrated Chl $a$ varied from $18-25 \mathrm{mg} \mathrm{m}^{-2}$ in summer and autumn to $72.5 \mathrm{mg}$ $\mathrm{m}^{-2}$ in winter (Table 1 ).

Suspended PN concentrations showed a maximum in the upper $50 \mathrm{~m}$ during most cruises (Figure $2 \mathrm{~d}$ ). The $0-50 \mathrm{~m}$ mean ranged from 0.2 to $0.7 \mu \mathrm{mol} \mathrm{L} \mathrm{L}^{-1}$, with higher values in winter and spring. PN decreased with depth and usually reached $0.1 \mu \mathrm{mol} \mathrm{L}{ }^{-1}$ at $150-200 \mathrm{~m}$. $\delta^{15} \mathrm{~N}$ of suspended PN, $\delta^{15} \mathrm{~N}$ (SUS), ranged from 0.4 to $8.4 \%$ (Figure 2e). It exhibited lower values $(0-3 \%)$ in the upper $50 \mathrm{~m}$ whereas higher values (>5\%) were found below $100 \mathrm{~m}$. Such a vertical increase was seen clearly in the high-resolution autumn profile (MR10-06; sampling interval: $5 \mathrm{~m}$ ) between 50 and $100 \mathrm{~m}$ depth (Figure 2e), which corresponds to a sharp $\delta^{15} \mathrm{~N}$ (SUS) increase across $\sigma_{\theta}=25 \mathrm{~kg} \mathrm{~m}^{-3}$ (Figure 3c). At the DCM during seasons other than winter, $\delta^{15} \mathrm{~N}(\mathrm{SUS})$ was ca. $3 \%$ (Table 1). Remarkably, it dropped to lower values below the DCM and increased again with depth, as illustrated in the $\sigma_{\theta}$ vs. $\delta^{15} \mathrm{~N}(\mathrm{SUS})$ plot (Figure 3d). Nitrate $\delta^{15} \mathrm{~N}$ showed a range of 4.2-6.4\%o, without apparent vertical change from 100 to $300 \mathrm{~m}$ (Figure 2f), even though nitrate concentrations decreased from 7 to 3 $\mu \mathrm{mol} \mathrm{L}{ }^{-1}$ over the same depth interval. Such a nearly uniform profile of nitrate $\delta^{15} \mathrm{~N}(3.7-4.7$ \%o) was also found nearby (410 km east of S1) in July 2014 during MR14-04 [Yoshikawa et al., 2018]. Note that in June 2012, there were statistically higher nitrate $\delta^{15} \mathrm{~N}$ values (>6\%o), which we cannot readily explain. DST experiments during each cruise showed that the mean PN flux at 100-200 m varied from 1.0 to $17 \mathrm{mg} \mathrm{m}^{-2} \mathrm{~d}^{-1}$ [in nitrogen (N) equivalents], with higher fluxes in February 2011 and June 2012 (Figure 4). The mean $\delta^{15} \mathrm{~N}$ of particles collected by DST, $\delta^{15} \mathrm{~N}(\mathrm{DST})$, ranged from 2.6 to $5.1 \%$, with the two lowest values $(<3.3$ $\%$ ) found to coincide with the two highest PN fluxes (Table 1).

\subsection{Temporal variations of fluxes and $\mathrm{PN}-\delta^{15} \mathrm{~N}$ of settling particles}

Moored sediment trap experiments during 2010-14 revealed temporal variations of particulate flux and $\delta^{15} \mathrm{~N}$ of trapped particles, $\delta^{15} \mathrm{~N}(\mathrm{MST})$, collected at $200 \mathrm{~m}$, which were closely linked with seasonal changes in the upper oceanic condition (Figure 5). After satellite sea surface temperature began to decrease in October, surface Chl $a$ started to increase in November-December to a peak (0.3-0.5 $\mathrm{mg} \mathrm{m}^{-3}$ ) around March-April (Figures 5a, b). Such winter increase of Chl $a$ is a typical feature in the western NPSG [Siswanto et al., 2015]. Winter convective deep mixing supplied nutrients into the euphotic layer, which would stimulate phytoplankton growth at S1 [Fujiki et al., 2016; Matsumoto et al., 2016]. Thereafter, Chl $a$ decreased to $<0.1 \mathrm{mg} \mathrm{m}^{-3}$ with SST increasing, attributable to nutrient limitation in the strongly stratified upper layer. These variations in satellite $\mathrm{Chl} a$ were validated by our hydrographic data from cruises in 2010-12. We define the period with surface Chl $a>0.1 \mathrm{mg} \mathrm{m}^{-3}$ in winter/spring as "bloom" period (Table 2), which is shaded in Figures 5 .

Total mass flux (TMF) at $200 \mathrm{~m}$ ranged from 5.4 to $592 \mathrm{mg} \mathrm{m}^{-2} \mathrm{~d}^{-1}$ (not shown). PN flux at the same depth ranged from 0.18 to $21.8 \mathrm{mg} \mathrm{m}^{-2} \mathrm{~d}^{-1}$ (Figure 5c). TMF and organic carbon flux (OCF) were significantly higher during the earlier of the five MST deployments, especially Trap-1 and Trap-3 (Table 3). The fluxes showed a clear seasonality. Higher particle fluxes appeared during phytoplankton blooms in winter/spring, with averages 2.4 and 1.6 times larger than TMF and OCF during non-bloom periods (Table 3), which was attributed to enhanced productivity. Exceptionally, two PN flux peaks $\left(9.4\right.$ and $5.1 \mathrm{mg} \mathrm{m}^{-2} \mathrm{~d}^{-}$ ${ }^{1}$ ) appeared in summer/autumn 2011 (Figure 5c) even when surface Chl $a$ concentrations were $<0.1 \mathrm{mg} \mathrm{m}^{-3}$. The limited data suggested that PN fluxes collected by MST were mostly smaller than those collected by DST during cruises in 2010-12 (Figure 5c), consistent with the findings of Honda et al. [2015]. They reported that the OCF collected by MST on average 
accounted for about $25 \%$ of the OCF collected by DST. This is probably due to differences in sampling period (MST: 6-18 days, DST: 3-4 days) and the trap design (MST: conical traps, DST: cylindrical traps) that would result in different hydrodynamic biases on trapping efficiency [Buesseler et al., 2007].

Trapped particles at $\mathrm{S} 1$ were composed mainly of organic material $(\mathrm{OM})$ and $\mathrm{CaCO}_{3}$ with little biogenic opal and lithogenic materials (Figure 5d), with flux-weighted average mass fraction of $50.7,44.8,2.9$, and $1.6 \%$, respectively, which is the typical feature of a "carbonate ocean" proposed by Honjo [1997]. Unlike particle fluxes, there was no significant difference in the two major contributions between trap deployments (Table 3). The $\mathrm{CaCO}_{3}$ mass fraction, $w\left(\mathrm{CaCO}_{3}\right)$, increased up to $60-70 \%$ during blooms while it decreased to $<40$ $\%$ during non-bloom periods (Figure $5 \mathrm{~d}$ ), which resulted in a significant difference of the mean $w\left(\mathrm{CaCO}_{3}\right)$ of $49 \%$ vs. $38 \%$ during bloom and non-bloom periods from 2010 to 2014, respectively (homoscedastic Student's $t$-test; $p=0.012$, Table 3 ). The opal mass fraction, $w$ (opal), also increased to $5-11 \%$ during blooms in $2010-12$ (Figure $5 \mathrm{~d}$ ). $\delta^{15} \mathrm{~N}(\mathrm{MST}$ ) varied from 2.3 to $6.2 \%$ (Figure 5e) with a flux-weighted average of $4.1 \%$ for the whole period of trap experiments. During the first half of blooms, $\delta^{15} \mathrm{~N}(\mathrm{MST})$ usually decreased to below 4 $\%$, with a minimum of 2-3\%o before increasing at the second half. This $\delta^{15} \mathrm{~N}(\mathrm{MST})$ drop appeared in December-January of 2011 and 2011/12, and in February of 2013 and 2014 although blooms started at a similar timing each year. Consequently, $\delta^{15} \mathrm{~N}(\mathrm{MST})$ remained below $4 \%$ for a month longer in 2011-12 than in 2013-14 (Table 2). As an exception, in August-September 2011, $\delta^{15} \mathrm{~N}(\mathrm{MST})$ decreased to below $4 \%$ when the flux was at the annual maximum (Figure 5e). $\delta^{15} \mathrm{~N}(\mathrm{DST})$ and $\delta^{15} \mathrm{~N}(\mathrm{MST})$ obtained at the same time were usually consistent with each other, except that $\delta^{15} \mathrm{~N}$ (DST) in June 2012 was $1 \%$ lower than $\delta^{15} \mathrm{~N}(\mathrm{MST})$ during MR12-02. This was attributable to a different sampling period of 3 days and 16 days for DST and MST particles, respectively. In other words, relatively low $\delta^{15} \mathrm{~N}$ particles $(3.3 \%$ ) were formed and trapped as DST particles for a period of 3 days while higher $\delta^{15} \mathrm{~N}$ particles were formed before and after it. Both particle fractions contributed to the MST particles collected for 16 days in June 2012 with average $\delta^{15} \mathrm{~N}$ of $4.3 \%$.

We plotted $\delta^{15} \mathrm{~N}(\mathrm{MST})$ against chemical compositions as well as fluxes of trapped particles in Figure 6. The particles associated with higher fluxes (i.e. $>200 \mathrm{mg} \mathrm{m}^{-2} \mathrm{~d}^{-1}$ of total mass and $>100 \mathrm{mg} \mathrm{m}^{-2} \mathrm{~d}^{-1}$ of $\mathrm{CaCO}_{3}$ flux during Trap-1 and 3) tended to have relatively low $\delta^{15} \mathrm{~N}$ values of 3-4 \% (Figures $\left.6 \mathrm{a}, \mathrm{d}\right)$. Meanwhile, $\delta^{15} \mathrm{~N}(\mathrm{MST})$ values from all deployments were correlated positively with $w(\mathrm{OM})$, and negatively with $w\left(\mathrm{CaCO}_{3}\right)(r=0.46$ and -0.44 , respectively) (Figures 6e, g). Consequently, a positive correlation was found with the mole ratio of organic carbon to inorganic carbon of particles, $R$ (POC:PIC), $(r=0.41)$ (Figure 6h). Note that the MST particles with $w$ (opal) of $>5 \%$ always showed lower $\delta^{15} \mathrm{~N}(<4 \%$ ) (Figure 6f).

\section{Discussion}

\subsection{Particle $\delta^{15} \mathrm{~N}$ and $\mathrm{N}$ source for $\mathrm{PN}$ formation in the upper layer}

Nutrient availability in the euphotic zone at S1 was higher in winter and lower in summer/autumn (Figure 2b). This was mainly controlled by the seasonal cycle of convective mixing and thermal stratification [Inoue and Kouketsu, 2016]. Consequently, phytoplankton biomass, i.e. depth-integrated $\mathrm{Chl} a$, exhibited a winter maximum followed by declines due to nutrient limitation (Figure 2c, Table 1). Matsumoto et al. [2016] reported the highest primary productivity ( $847 \mathrm{mg} \mathrm{m}^{-2} \mathrm{~d}^{-1}$ in carbon equivalents) in winter (February), which was larger than twice the annual mean (303-369 $\mathrm{mg} \mathrm{m}^{-2} \mathrm{~d}^{-1}$ ). In stratified seasons, the DCM appeared slightly above the $\sigma_{\theta}=25.0-25.5 \mathrm{~kg} \mathrm{~m}^{-3}$ isopycnal (Figure $3 \mathrm{~b}$ ), known as North Pacific 
subtropical mode water, STMW [Qiu et al., 2006; Oka et al., 2009], implying that nutrient input from STMW sustained the DCM.

Despite seasonal changes of $\mathrm{Chl} a$ as well as nitrate concentration, $\delta^{15} \mathrm{~N}(\mathrm{SUS})$ always exhibited lower values $(<3 \%$ ) at $10-50 \mathrm{~m}$ and increased to $>5 \%$ with depth, except for winter when low $\delta^{15} \mathrm{~N}$ (on average $1.4 \%$ ) appeared throughout the well-mixed column (Figure 2e). Such low $\delta^{15} \mathrm{~N}$ (SUS) in nitrate-depleted surface waters imply that phytoplankton growth relied on another $\mathrm{N}$ source with low $\delta^{15} \mathrm{~N}$. Two possible sources are recycled $\mathrm{N}$ such as ammonium, and $\mathrm{N}_{2}$ fixation. It has been suggested that $\mathrm{NH}_{4}{ }^{+}$with low $\delta^{15} \mathrm{~N}$ is produced via zooplankton excretion [Checkley and Miller, 1989] and microbial decomposition of organic matter (especially DON deamination, Knapp et al. [2012]). Recycled $\mathrm{NH}_{4}{ }^{+}$uptake by phytoplankton, mainly cyanobacteria, would add low $\delta^{15} \mathrm{~N}$ particles to the suspended PN pool [Altabet et al., 1988; Mino et al., 2002; Fawcett et al., 2011, 2014]. Heterotrophic bacteria can also utilize recycled $\mathrm{N}$ and the detritus derived from these prokaryotes would contribute to a lower $\delta^{15} \mathrm{~N}$ of the PN pool [Fawcett et al., 2011]. At S1, dominant picophytoplankton actively release DOC during spring to autumn [Matsumoto et al., 2016], which would stimulate the microbial food web and $\mathrm{NH}_{4}{ }^{+}$recycling in it. Also, $\mathrm{N}_{2}$ fixation by diazotrophs can provide low $\delta^{15} \mathrm{~N}$ particles ( -2 to $+1 \%$ ) [Minagawa and Wada, 1986; Dore et al., 2002; Montoya et al., 2002]. During all cruises in 2010-13, the filamentous $\mathrm{N}_{2}$ fixing Trichodesmium was found only in quite small numbers at $\mathrm{S} 1$ by light-microscopic examination. Nano-sized unicellular cyanobacteria, some of which can use $\mathrm{N}_{2}$ fixation [Zehr et al., 2001 etc.], were not detected as a distinct cluster in our flow cytometric cytogram, which is consistent with Sato et al. [2010] who reported a lower abundance of them in the northern areas $\left(27^{\circ} \mathrm{N}\right)$ in the NPSG. These results imply that $\mathrm{N}_{2}$ fixation should have a limited "direct" effect on $\delta^{15} \mathrm{~N}(\mathrm{SUS})$ in the upper waters. However, nitrogen fixed by diazotrophs at some earlier point in time could remain in the euphotic layer during the stratified season via $\mathrm{NH}_{4}{ }^{+}$recycling [Mino et al., 2002], which is reflected by a lower $\delta^{15} \mathrm{~N}$ signature of nitrogen recycled in the surface ecosystem.

At the DCM slightly above the nitracline, $\delta^{15} \mathrm{~N}(\mathrm{SUS})$ was usually ca. $3 \%$ (Table 1 ). This relatively high PN- $\delta^{15} \mathrm{~N}$ implies that new nitrate with $\delta^{15} \mathrm{~N}(>4 \%$ ) was utilized for PN formation. Fawcett et al. [2011] suggested that only eukaryotic phytoplankton assimilate new nitrate in the oligotrophic upper waters of the Sargasso Sea (station BATS). Assuming this was also the case for $\mathrm{S} 1$, higher $\mathrm{PN}-\delta^{15} \mathrm{~N}$ values at the DCM may be a reflection of the observed algal taxonomic composition [Fujiki et al., 2016], which showed eukaryotes accounting for $(65 \pm 10) \%$ of total Chl $a$ at the DCM, but only (39 \pm 4$) \%$ at $0-30 \mathrm{~m}$ (Figure $\mathrm{S} 2)$. In other words, the DCM particles would inherit the $\delta^{15} \mathrm{~N}$ signal of the PN formed from new nitrate by eukaryotic phytoplankton. Moreover, we found slight $\delta^{15} \mathrm{~N}(\mathrm{SUS})$ decreases below the DCM (Figure 3d). In June 2012, these drops appeared at higher $\sigma_{\theta}$ values than in July 2011 ( 25.1 vs. $24.9 \mathrm{~kg} \mathrm{~m}^{-3}$ ), which followed the $\sigma_{\theta}$ values for DCM waters in both periods (24.8-25.1 vs. $24.5-25.0 \mathrm{~kg} \mathrm{~m}^{-3}$, Figure $3 \mathrm{~b}$ ). Such $\mathrm{PN}-\delta^{15} \mathrm{~N}$ drops could be attributed to high nitrate availability in those waters $\left(>0.4 \mu \mathrm{mol} \mathrm{L}^{-1}\right.$ in concentration), which would lead to low $\delta^{15} \mathrm{~N}$ particles from partial nitrate assimilation by phytoplankton. Thus, $\delta^{15} \mathrm{~N}$ (SUS) corroborated that the PN around the DCM originated mostly from STMW nitrate.

$\delta^{15} \mathrm{~N}(\mathrm{DST})$ at $100-200 \mathrm{~m}$ varied seasonally from 2.6 to $5.1 \%$, which was generally higher than average $\delta^{15} \mathrm{~N}$ (SUS) in the upper $100 \mathrm{~m}$ and even higher than the DCM $\delta^{15} \mathrm{~N}(\mathrm{SUS})$ at the same time (Table 1). Relatively high $\mathrm{PN}-\delta^{15} \mathrm{~N}$ export via particle settling from the oligotrophic mixed layer has been reported in station BATS [e.g. Altabet, 1988]. Zooplankton fecal pellets may originate mainly from PN formed using new nitrate rather than recycled $\mathrm{N}$. In this scenario, herbivorous zooplankton would preferentially consume the nitrate-user, eukaryotic phytoplankton, and thereby imprint relatively high eukaryote $\delta^{15} \mathrm{~N}$ values onto 
their fecal pellets [Fawcett et al., 2011]. If so, such fecal pellets and/or the bulk trapped particles including them could record nitrate availability when the original PN was formed photosynthetically. Actually, our observed variations in $\delta^{15} \mathrm{~N}(\mathrm{DST})$ relate closely to nitrate availability in the upper layer, since the two lowest $\delta^{15} \mathrm{~N}(\mathrm{DST})$ values were associated with larger PN fluxes in February 2011 and June 2012 (Figure 4). Winter low $\delta^{15} \mathrm{~N}(\mathrm{DST}$ ) agreed with highest nitrate availability (with $0.4 \mu \mathrm{mol} \mathrm{L}^{-1}$ in concentration) in a mixed water column that would favor formation of low $\delta^{15} \mathrm{~N}$ particles due to isotopic fractionation. By contrast, nitrate was almost depleted in early summer 2012 (Table 1) when relatively large PN fluxes with lower $\mathrm{PN}-\delta^{15} \mathrm{~N}$ were found.

In June 2012, we found the DCM at shallower depths, albeit at higher $\sigma_{\theta}$ values, than those seen in autumn 2010 and summer 2011 (Figures 2c, 3b). This shallower, high- $\sigma_{\theta}$ DCM might be due to deeper waters having been lifted up temporally to the euphotic zone.

Actually, nitrate depletion appeared in denser waters $\left(\sigma_{\theta}>25 \mathrm{~kg} \mathrm{~m}^{-3}\right)$ than during other periods (Figure S1), implying that nitrate in the upper STMW had been consumed. Based on observations and numerical simulations, Sukigara et al. [2014], Inoue et al. [2016], and Honda et al. [2018] reported that mesoscale eddy passages caused a temporal uplift of mode waters in the northwestern NPSG, which would transport nutrients into the euphotic zone and stimulate phytoplankton growth in the stratified season. Furthermore, the DST particles comprised $49 \% \mathrm{CaCO}_{3}$ by mass, similar to winter particles (47\%). These $\mathrm{CaCO}_{3}$ mass fractions were significantly higher than those in other seasons (23-38\%) [Honda et al., 2015]. Since nutrient input usually stimulates calcifying plankton (i.e. $\mathrm{CaCO}_{3}$ producers) at S1, this might explain the observations in early summer 2012. However, this temporal nutrient input had stopped before the June 2012 cruise when we found neither high biomass nor high productivity (Table 1). The PN with low $\delta^{15} \mathrm{~N}$ produced from new nitrate probably stayed in the upper ecosystem for a time, before being removed as settling particles. This can explain the low $\delta^{15} \mathrm{~N}(\mathrm{DST})$ signals seen in June 2012. Thus, $\delta^{15} \mathrm{~N}(\mathrm{DST})$ variations reflect nitrate availability during photosynthetic PN formation.

\subsection{Relative contribution of new $\mathrm{N}$ sources to the export production at $\mathrm{S} 1$}

In the upper ocean with relatively high current velocities, hydrodynamic effects on the trap collection will be more prevalent than in deep ocean traps, which represents a source of uncertainty in particle flux measurement by shallow traps. In particular, it has been suggested that conical traps, which we used in this study, tend to under-collect because the particles that settle into the trap can be swept out by flows entering the traps and swirls in it [Buesseler et al., 2007]. In fact, the mean annual POC export $\left(0.365 \mathrm{~mol} \mathrm{~m}^{-2} \mathrm{a}^{-1}\right)$ based on our MST at 200 $\mathrm{m}$ at $\mathrm{S} 1$ was a factor of 5.5 smaller than the lowest estimate from the upper ocean carbon mass balance (1.99 $\mathrm{mol} \mathrm{m}^{-2} \mathrm{a}^{-1}$; Wakita et al., 2016), implying a low trapping efficiency of our shallow traps. As for particle properties, however, deep trap particles have more varied origins due to particle advection, which is greater for slow-settling than fast-settling particles [e.g. Siegel and Deuser, 1997]. In addition, particles could undergo biogenic transformations during their long trip to the deep sea. Shallow traps are less influenced by these effects because less time is available for differential settling, particle supply from distant regions and biogenic transformations [Buesseler et al., 2007]. We therefore interpret $\mathrm{PN}-\delta^{15} \mathrm{~N}$ and chemical compositions of the MST particle at $200 \mathrm{~m}$ as representative of the condition of particle sources directly above the trap at $\mathrm{S} 1$.

At steady state, the isotope fluxes in and out of the upper layer must balance such that the $\mathrm{PN}-\delta^{15} \mathrm{~N}$ exported from the upper water is equal to the weighted average $\delta^{15} \mathrm{~N}$ of the new nitrogen entering the system [Montoya et al., 2002]. The flux-weighted average $\delta^{15} \mathrm{~N}$ of the MST particles at $200 \mathrm{~m}$ was $4.1 \%$ during the entire experimental period, somewhat lower 
than the mean nitrate $\delta^{15} \mathrm{~N}$ of $(4.9 \pm 0.8) \%$ for all data $(n=17)$ or $(4.5 \pm 0.4) \%$ for the data excluding June $2012(n=12)$. This difference of 0.4 to $0.8 \%$ implies another ${ }^{15} \mathrm{~N}$-depleted source for PN formation. If $\mathrm{N}_{2}$ fixation ( $-1 \%$, Minagawa and Wada [1986]) corresponded to this $\delta^{15} \mathrm{~N}$ imbalance, its relative contribution to total new $\mathrm{N}$ input (i.e. export production) would be $7-14 \%$. This limited contribution of $\mathrm{N}_{2}$ fixation is consistent with the small number of $\mathrm{N}_{2}$ fixing cyanobacteria found at $\mathrm{S} 1$, and a large amount of nitrate supplied via winter mixing. This is in contrast to relatively high $\mathrm{N}_{2}$ fixation reported at station ALOHA (e.g. 36-69 \%, Dore et al., [2002]; 26-47 \%, Böttjer et al. [2017]) where summer increases of diazotrophs were often observed and no winter bloom occurred. In term of $\mathrm{N}_{2}$ fixation, station S1 is similar to BATS where it accounts for several percent at most (Altabet, 1988; Orcutt et al., 2001; Knapp et al., 2005). However, note that nitrate $\delta^{15} \mathrm{~N}$ data used for evaluating the end-member for new nitrate showed nearly uniform profiles at 100-300 m (Figure 2f) in the upper STMW even with the nitrate concentration decreasing toward the surface. This indicates the presence of a low $\delta^{15} \mathrm{~N}$ source such as $\mathrm{N}_{2}$ fixation [Yoshikawa et al., 2018]. That is, some nitrogen fixed by diazotrophs may have subsequently been converted to nitrate via nitrification, adding a low $\delta^{15} \mathrm{~N}$ signal to the subsurface nitrate pool. This may cause underestimation of $\mathrm{N}_{2}$ fixation. However, given that the STMW originates from Kuroshio water, it is reasonable to attribute this effect to the $\mathrm{N}$ fixed in the southern upstream Kuroshio Current where diazotrophs were generally found [Shiozaki et al., 2010], as suggested by Yoshikawa et al. [2018]. In this case, our estimate would correspond to the average contribution of $\mathrm{N}_{2}$ fixation in the $\mathrm{S} 1$ region.

\subsection{Convective nitrate supply recorded as winter drops of $\delta^{15} \mathrm{~N}(\mathrm{MST})$}

Our calculation suggests that nitrate supplied from below mainly (86-93\%) sustained new production at S1. Therefore, observed $\delta^{15} \mathrm{~N}(\mathrm{MST})$ variations of ca. $4 \%$ would reflect seasonal changes in euphotic zone nitrate availability. $\delta^{15} \mathrm{~N}(\mathrm{MST})$ showed steep drops, followed by increases, during every winter bloom with larger fluxes (Figure 5e). The preceding drop to $3 \%$ was caused by the supply of new nitrate via convective mixing, which would enhance photosynthetic PN formation with low $\delta^{15} \mathrm{~N}$ due to isotope fractionation. This was consistent with the winter cruise observation with relatively low $\delta^{15} \mathrm{~N}(\mathrm{SUS})$ and $\delta^{15} \mathrm{~N}\left(\mathrm{DST}\right.$ ) in February 2011 (Table 1). This ${ }^{15} \mathrm{~N}$ fractionation during nitrate consumption would elevate the $\delta^{15} \mathrm{~N}$ of the remaining nitrate after convective input was reduced or stopped. Then, this high $\delta^{15} \mathrm{~N}$ signal would be imprinted into PN via subsequent nitrate assimilation by phytoplankton, which can explain why $\delta^{15} \mathrm{~N}(\mathrm{MST})$ increased beyond the STMW nitrate $\delta^{15} \mathrm{~N}(4.5-4.9 \%$ ) in the late stage of blooms (Figure 5e).

Focusing on the timing of the $\delta^{15} \mathrm{~N}(\mathrm{MST})$ decrease to $<4 \%$, it appeared with shorter time lag from the bloom initiations (when surface $\mathrm{Chl} a$ concentration exceeded $>0.1 \mathrm{mg} \mathrm{m}^{-3}$ ) in 2011-12 compared with those in 2013-14 (Table 2, Figure 7). Assuming that each bloom is initiated at the beginning of the nitrate supply, immediate drops of $\delta^{15} \mathrm{~N}(\mathrm{MST})$ in 2011-12 suggested that excess nitrate was supplied relative to the consumption by phytoplankton that would assimilate ${ }^{14} \mathrm{NO}_{3}{ }^{-}$preferentially (Figure 7a). On the other hand, for the first 1.5 months of the blooms in 2013-14, $\delta^{15} \mathrm{~N}(\mathrm{MST})$ stayed around 4.5-5.0 \%o (Figure 7b), essentially equal to the $\delta^{15} \mathrm{~N}$ of the nitrate source. This implied that all nitrate supplied was consumed so that its original $\delta^{15} \mathrm{~N}$ would be imprinted on the MST particles (i.e. no nitrogen isotope fractionation occurred). During the early bloom period (around the end of January), the surface Chl $a$ increase was limited to $0.2 \mathrm{mg} \mathrm{m}^{-3}$ (Figure 5b). If algal consumption in this period was comparable over different years, more nitrate would be supplied during the early bloom in 2011-12 when $\delta^{15} \mathrm{~N}(\mathrm{MST})$ decreased, relative to 2013-14 with constant $\delta^{15} \mathrm{~N}(\mathrm{MST})$. This hypothesis is consistent with interannual differences in particle 
composition. Typically, high $w\left(\mathrm{CaCO}_{3}\right)$, likely derived from coccolithophore tests [IglesiasRodríguez et al., 2002], was associated with low $\mathrm{PN}-\delta^{15} \mathrm{~N}$ in the MST particles during winter blooms (Table 3, Figure 6g). As seen in Figure 7, both concentrations of organic matter and $\mathrm{CaCO}_{3}$ in MST particles varied depending on how the blooms developed. In 2011-12, $w\left(\mathrm{CaCO}_{3}\right)$ reached 60-70 \% during the early stage of the bloom, then it declined and was replaced by $w(\mathrm{OM})$ in the middle stage (80-100 days after bloom initiations) (Figure 7a). This likely resulted from a quick growth of coccolithophores responding to nutrient supply, especially phosphate [e.g. Riegman et al., 2000] and subsequent phytoplankton succession to non-calcifying cells. In $2013-14$, however, $w\left(\mathrm{CaCO}_{3}\right)$ ranged from 50 to $60 \%$ and only slightly exceeded $w(\mathrm{OM})$ with $40-50 \%$ even in the early bloom (0-45 days) (Figure 7b). These moderate $w\left(\mathrm{CaCO}_{3}\right)$ values in $2013-14$ could be associated with a relatively small supply of nitrate. Furthermore, winter decreases of $\delta^{15} \mathrm{~N}(\mathrm{MST})$ in 2011-12 were accompanied by increased $w$ (opal) of 5-12\% (Figures $5 \mathrm{~d}$, and $6 \mathrm{f}$ ), implying that diatoms also thrived. In fact, large $(>10 \mu \mathrm{m})$ diatoms Chaetoceros spp. and Pseudo-nitzschia spp. dominated during the bloom in February 2011 [Fujiki et al., 2016]. On the other hand, $w$ (opal) remained $<5 \%$ in 2013-14, which suggested that the turbulence regime in those years did not favor diatom growth [Eppley and Thomas, 1969; Margalef, 1978].

Following the steady $\delta^{15} \mathrm{~N}(\mathrm{MST})$ of around 4.5-5.0 \%o in the early bloom in 2013-14, it eventually decreased to $<4 \%$ in February (54 days after bloom initiation; Figure $7 \mathrm{~b}$ ), which indicates that further nitrate supply occurred that exceeded algal consumption. Such quasi-two-phased supply was verified by another mooring deployment of an underwater profiling buoy system [Fujiki et al., 2008; Inoue et al., 2016; Fujiki et al., 2019] that provided continuous CTD and Chl $a$ data (per every 6 days) from July 2012 to March 2013. Figure 8 showed that the mixed-layer started to deepen from mid-October 2012 (yearday 293) by ocean cooling, and reached ca. $80 \mathrm{~m}$ at the end of November (yearday 335). At that time, the mixed layer Chl $a$ concentration increased to $>0.1 \mathrm{mg} \mathrm{m}^{-3}$, signifying the initiation of phytoplankton bloom (Figure 8b). At the end of December (yearday 358), Chl $a$ increased to $0.15 \mathrm{mg} \mathrm{m}^{-3}$ with the MLD deepening to $100 \mathrm{~m}$. After that, interspersed with temporal restratifications, abrupt MLD deepenings to $>140 \mathrm{~m}$ occurred in mid-January and February (yeardays 382, 394, and 406), followed by a Chl $a$ concentration increased to $0.25-0.3 \mathrm{mg} \mathrm{m}$ 3 . This latter Chl $a$ growth was probably triggered by the enhanced nutrient supply provided by these deeper mixings, which caused the $\delta^{15} \mathrm{~N}(\mathrm{MST})$ drop in February 2013 that appeared ca. 2 months after the bloom initiation (Figure 8c). Such abrupt MLD deepening in late January 2013 seemed consistent with seasonal transitions of the air-sea net heat flux (NHF) at $\mathrm{S} 1$ in Figure 9 (black line) where negative values indicate oceanic heat loss. From October 2012, weekly mean NHF decreased to $-300 \mathrm{~W} \mathrm{~m}^{-2}$ until December 2012 (i.e. ocean cooling), but temporally increased to $-200 \mathrm{~W} \mathrm{~m}^{-2}$ at the year-end, then returned to the minimum $(<-$ $300 \mathrm{~W} \mathrm{~m}^{-2}$ ). This enhanced oceanic heat loss in late January 2013 would deepen the MLD to over $140 \mathrm{~m}$ (Figure $8 \mathrm{a}$ ). The previous temporal reduction of heat loss could have delayed the progress of MLD deepening. In contrast, the 2011 minimum NHF (ca. $-400 \mathrm{~W} \mathrm{~m}^{-2}$ ) appeared at the beginning of the year (gray line, Figure 9) when $\delta^{15} \mathrm{~N}(\mathrm{MST})$ dropped immediately after bloom initiation. Such more intense cooling in January 2011 than in 2013 was attributable to an enhanced winter monsoon, as indicated by a East Asian Winter Monsoon Index (MOI, Hanawa et al. [1988], 24.633 in 2011 vs. 21.667 in 2013). These interannual variations of winter cooling likely controlled both timing and magnitude of nutrient supply due to convective mixing. As a result, the total period with $\delta^{15} \mathrm{~N}(\mathrm{MST})$ of $<4 \%$, indicating higher nitrate availability, was about a month longer in 2011-12 than in 2013-14 (Table 2, Figure 7). These variations are reflected in the flux-average $w\left(\mathrm{CaCO}_{3}\right)$ of particles, which was ca. 8 $\%$ higher in 2011-12 than in 2013-14 (Table 4). Moreover, the $R$ (POC:PIC) ratio was significantly lower in 2011-12 than in 2013-14 (1.6-2.0 vs. 2.7-3.2, Table 4). Therefore, the 
higher nutrient supply during the 2011-12 bloom favored growth of calcifying plankton, which accounted for higher particulate fluxes during blooms in 2011-12 (Table 3).

\subsection{Input of nitrate inferred from $\delta^{15} \mathrm{~N}(\mathrm{MST})$ decrease in summer 2011}

Two exceptionally large PN flux peaks appeared in August-September and November 2011, even though the surface Chl $a$ concentration was $<0.1 \mathrm{mg} \mathrm{m}^{-3}$ (Figures $5 \mathrm{~b}, \mathrm{c}$ ). A marked drop of $\delta^{15} \mathrm{~N}(\mathrm{MST})$ to $3.5 \%$ was found during the first peak, but not during the second one (Figure 5e). Inoue et al. [2016], by using time-series (every 3 days) of upper layer CTD and Chl $a$ data from the S1 mooring during the summer of 2011, attributed the first peak to the eddy-driven uplift of nutrient-rich waters that would enhance subsurface productivity. This is because an increased $\mathrm{Chl} a$ concentration $\left(0.7 \mathrm{mg} \mathrm{m}^{-3}\right)$ in the DCM appeared when its depth shoaled from $100 \mathrm{~m}$ to $80 \mathrm{~m}$ when the edge of a cyclonic eddy passed S1. The concurrent $\delta^{15} \mathrm{~N}(\mathrm{MST})$ drop we observed verifies that new nitrate was supplied into the euphotic zone and stimulated the flux peak that lasted over a month. During the June 2012 cruise, we also found a temporal uplift of deep waters to the euphotic zone (see Section 4.1), i.e. the DCM and nitrate depletion appeared in relatively dense waters (Figures 2c, 3b, S1), which led to low PN- $\delta^{15} \mathrm{~N}$ (3.3 \%o) of DST particles collected for 3 days (Figure 4). However, given that it resulted in only a small $\delta^{15} \mathrm{~N}(\mathrm{MST})$ drop to $4.3 \%$ over a16 day-interval (Figure $5 \mathrm{e}$ ), enhanced $\mathrm{N}$ availability would not be sustained for weeks. Compared with this, the marked $\delta^{15} \mathrm{~N}(\mathrm{MST})$ during August-September 2011 indicated larger and longer new nitrate input, which led to a PN peak flux of $10 \mathrm{mg} \mathrm{m}^{-2} \mathrm{~d}^{-1}$, comparable to or exceeding the PN flux during winter blooms in 2010-2012 (Figures 5c). This supports that even eddy-related supply of nutrients of only short duration has a significant impact on particle formation in oligotrophic subtropics (the Atlantic: McGillicuddy et al. [2007], NPSG: Sukigara et al. [2014] and Honda et al. [2018]).

However, it is worth noting that $w\left(\mathrm{CaCO}_{3}\right)$ in MST particles remained only $25 \%$ during these peak fluxes in summer 2011 (Figure 5d), resulting in $R$ (POC:PIC) of 8.7 (Table 4). This was in contrast to the winter MST particles with $50-70 \%$ of $w\left(\mathrm{CaCO}_{3}\right)$ during blooms. Relatively low $w\left(\mathrm{CaCO}_{3}\right)$ means that summer input of nutrients may not stimulate calcifying plankton. Moreover, such nutrients must have been consumed in the lower euphotic zone because surface $\mathrm{Chl} a$ did not increase $\left(<0.1 \mathrm{mg} \mathrm{m}^{-3}\right)$ (Figure $5 \mathrm{~b}$ ). These facts cast a doubt whether the nutrient transport via vertical heaving in summer was comparable to that via winter convection, even when particulate fluxes were equivalent at both times.

Alternatively, peak fluxes in summer may have resulted from particles advected from upstream of the eddy where larger vertical heaving occurred [Inoue et al., 2016]. If during such particle advection "settleable" aggregate with $\mathrm{CaCO}_{3}$ ballast was removed preferentially (see discussion in Section 4.5), this may account for lower $w\left(\mathrm{CaCO}_{3}\right)$ in the particles trapped at S1, downstream of the eddy. Presumably, passage of an eddy can not only cause vertical nutrient transport into the euphotic zone, but also re-distribute the formed particles by advection. Particle advection also possibly explains the second peak in flux found in November 2011 when another eddy approached S1.

However, as there are no data to evaluate this hypothesis, it needs to be addressed in a future observational study on ocean eddies. Such a study will have to give careful consideration to $\delta^{15} \mathrm{~N}$ of the nitrate supplied via uplift of the subsurface water, which directly affects the particle $\delta^{15} \mathrm{~N}$. If nitrate with relatively low $\delta^{15} \mathrm{~N}(3.7-4.5 \%$, Fig. 2f) is supplied, this new $\mathrm{N}$ input would be recorded as more remarkable drop of the formed particle $\delta^{15} \mathrm{~N}$. Conversely, it becomes smaller when nitrate $\delta^{15} \mathrm{~N}$ is the same or higher than typical value (4.5-4.7\%o). That is, its temporal and horizontal distributions should be examined with more data of nitrate $\delta^{15} \mathrm{~N}$ in the upper STMW during stratified seasons. 
4.5 Implication of new nitrate-stimulated $\mathrm{CaCO}_{3}$ export during blooms on carbon cycle in the northwestern NPSG

Our trapped particles at $200 \mathrm{~m}$ during the entire experimental period consisted of $\mathrm{CaCO}_{3}$ weighing $45 \%$ of total mass. Particularly during the early bloom triggered by new nitrate supply via winter convection, $w\left(\mathrm{CaCO}_{3}\right)$ increased to $>60 \%$ (Figure 7), which was attributed to enhanced $\mathrm{CaCO}_{3}$ production by coccolithophores, just as at the western North Atlantic subtropical gyre station BATS where an enhanced coccolith flux was seen in winter [Haidar et al., 2000]. Nevertheless, coccolithophores usually account for at most $20 \%$ of total primary production in subtropical waters [Balch et al., 1996; Poulton et al., 2006], which was also supported by photosynthetic pigment data at $\mathrm{S} 1$ showing that prymnesiophytes (including coccolithophores and others) seasonally comprised 13-30\% of total Chl $a$ in phytoplankton assemblages [Fujiki et al., 2016]. Given a $20 \%$ contribution of their POC productivities with a cellular calcification to photosynthesis ratio of 0.7 [Paasche, 2002], the POC:PIC production ratios in the upper layer would be 7.1. In this case, low $R$ (POC:PIC) $<2.0$ for most MST particles in the early bloom required that coccoliths were removed with 3.6 times higher efficiency than the organic carbon produced. Probably, such efficient $\mathrm{CaCO}_{3}$ transport was achieved by increased settling velocity of the aggregates including coccoliths [Schmidt et al., 2014; Bach et al., 2016]. Actually Sukigara et al. [2019] reported that the (hydrostatic) settling velocity of DST particles at S1, estimated by using an elutriation technique, was positively correlated with $w\left(\mathrm{CaCO}_{3}\right)$, which indicates more "settleable" aggregates including more calcite with higher density. In contrast, less dense, $\mathrm{OM}$ rich-particles and even aggregates without $\mathrm{CaCO}_{3}$ ballast settle less readily and would undergo much degradation within the upper layer at steady state [Armstrong et al., 2002; Fischer and Karakas, 2009]. In addition, these particles would settle more slowly due to enhanced turbulence in winter convective mixed layer [Noh and Nakada, 2010]. That is to say, winter mixing acts to screen out less dense particles (with less $\mathrm{CaCO}_{3}$ ) from particulate fluxes while it stimulates calcification by coccolithophores via nutrient supply. Conceivably, relatively strong convection in winter $2011-12$ contributed to higher $w\left(\mathrm{CaCO}_{3}\right)$ in trapped particles than in 2013-14 (discussed in Section 4.3), via more severe particle screening.

Thus, $\mathrm{CaCO}_{3}$ in trapped particles would facilitate downward transport of POC, at least for the "carbonate ballast-associated" organic matter, to the deep sea [Armstrong et al., 2002 etc.]. Meanwhile, preferential $\mathrm{CaCO}_{3}$ export over organic carbon from the upper waters, i.e. reduced $R$ (POC:PIC), can affect air-sea $\mathrm{CO}_{2}$ fluxes through increasing the seawater partial pressure of $\mathrm{CO}_{2}, p\left(\mathrm{CO}_{2}\right)$ [e.g. Honda et al., 1997; Shutler et al., 2013]. This is because calcification leads to a disequilibrium in the carbonate systems, with $0.6 \mathrm{~mol}$ of $\mathrm{CO}_{2}$ being produced per mole of $\mathrm{CaCO}_{3}$ deposited [Gattuso et al., 1995]. If $R$ (POC:PIC) becomes smaller (more $\mathrm{CaCO}_{3}$ flux), more alkalinity would be removed per DIC removed, which decreases $\mathrm{CO}_{3}{ }^{2-}$ concentration and increases $p\left(\mathrm{CO}_{2}\right)$, thus reducing ocean $\mathrm{CO}_{2}$ uptake rate [Emerson and Hedges, 2008]. An elevated R(POC:PIC) leads to the opposite situation. In winter to spring, $\mathrm{S} 1$ is a sink for atmospheric $\mathrm{CO}_{2}$ because of increased solubility due to ocean cooling as well as enhanced productivity [Wakita et al., 2016]. This $\mathrm{CO}_{2}$ uptake can be modulated by the interannual shift in winter $R$ (POC:PIC), as we found in 2011-14 (it varied twofold at the maximum, Table 4), depending on the monsoon intensity. These effects need to be considered when predicting future $\mathrm{CO}_{2}$ uptake rate in the northwestern NPSG, which holds a relatively large inventory of anthropogenic $\mathrm{CO}_{2}$ among marine provinces of the North Pacific basin [Khatiwala et al., 2013; Kouketsu et al., 2013]. 


\section{Conclusion}

We revealed that upper-layer particle $\delta^{15} \mathrm{~N}$ at the subtropical S1 varied depending on the availability of new N. 86-93\% of new N was supplied by nitrate from waters below. Reduced $\delta^{15}$ N(MST) during every winter from 2010 to 2014 and in summer 2011 indicated that nitrate was supplied via convective mixing and uplift of subsurface waters. The magnitude of convective nitrate supply varied from year to year, depending on winter monsoon intensity, which controlled downward particulate fluxes and flux composition. Convective mixing generally enhances $\mathrm{CaCO}_{3}$ export, likely derived from coccolithophore tests, hence increases $w\left(\mathrm{CaCO}_{3}\right)$ and reduces $R$ (POC:PIC) of exported particles at $\mathrm{S} 1$. This can influence air-sea $\mathrm{CO}_{2}$ fluxes there. Thus, at $\mathrm{S} 1$ in the northwestern NPSG, the primary source of new $\mathrm{N}$ is from convective mixing and uplift of nitrate-rich waters, unlike in the eastern NPSG, at station ALOHA, where $\mathrm{N}_{2}$ fixation contributes more substantially. This is due to the deeper mixing ( $>200 \mathrm{~m}$ ) caused by intense cooling in winter, which is rather similar to the BATS time series station in the western subtropical North Atlantic with winter MLDs of 150 to $300 \mathrm{~m}$ [Steinberg et al., 2001]. Since global warming is expected to weaken the East Asian Winter Monsoon [Hori and Ueda, 2006], convective mixing and associated nitrate enrichment will reduce in this region. Further measurements of trapped $\mathrm{PN}-\delta^{15} \mathrm{~N}$ and chemical compositions are needed to assess whether the primary new $\mathrm{N}$ source will shift from nitrate to other sources ( $\mathrm{N}_{2}$ fixation, atmospheric deposition etc.) and how this affects carbon sequestration in the NPSG.

\section{Acknowledgments, and Data}

The observational data from hydrographical cruises and mooring experiments in S1 are available on Japan Agency for Marine-Earth Science and Technology (JAMSTEC) K2S1 database (https://ebcrpa.jamstec.go.jp/k2s1/en/index.html). We are grateful to the officers and crew of the R/V Mirai for their support during the cruise and to the participants from Marine Works Japan Ltd. and Global Ocean Development Inc. for their on-board analysis and deck works. We also thank Alina Marca, University of East Anglia, UK, for her support of nitrate $\delta^{15} \mathrm{~N}$ analyses, and thank E. R. Maúre, Northwest Pacific Region Environmental Cooperation Center (NPEC), Japan, for his assistant to analyze OAFlux datasets. We are also grateful to anonymous reviewers, whose comments and suggestions significantly improved the content of this manuscript. This work was supported by JAMSTEC K2S1 project and KAKENHIOMIX (grant-in-aid for scientific research in innovative areas JP15H05822).

\section{References}

Altabet M. A. (1988), Variations in nitrogen isotopic composition between sinking and suspended particles: implications for nitrogen cycling and particle transformation in the open ocean, Deep-Sea Res., 35, 535-554.

Altabet M. A., W. G. Deuser, S. Honjo, and S. Stienen (1991), Seasonal and depth-related changes in the source of sinking particles in the N. Atlantic, Nature, 354, 136-139.

Altabet M. A., and R. Francois (1994), Sedimentary nitrogen isotopic ratio as a recorder for surface ocean nitrate utilization, Global Biogeochem. Cycles, 8, 103-116.

Armstrong R. A., C. Lee, J. I. Hedges, S. Honjo, and S. G. Wakeham (2002), A new, mechanistic model for organic carbon fluxes in the ocean based on the quantitative association of POC with ballast minerals, Deep-Sea Res. II, 49, 219-236. 
Bach L. T., T. Boxhammer, A. Larsen, N. Hildebrandt, K. G. Schulz, and U. Riebesell (2016), Influence of plankton community structure on the sinking velocity of marine aggregates, Global Biogeochem. Cycles, 30, 1145-1165.

Balch W. M., J. Fritz, and E. Fernandez (1996), Decoupling of calcification and photosynthesis in the coccolithophore Emiliania huxleyi under steady-state light-limited growth, Mar. Ecol. Prog. Ser., 142, 87-97.

Böttjer D., J. E. Dore, D. M. Karl, R. M. Letelier, C. Mahaffey, S. T. Wilson, J. Zehr, and M. J. Church (2017), Temporal variability of nitrogen fixation and particulate nitrogen export at Station ALOHA, Limnol. Oceanogr., 62, 200-216.

Buchwald C., and K. L. Casciotti (2013), Isotopic ratios of nitrite as tracers of the sources and age of oceanic nitrite, Nat. Geosci., 6, 308-313.

Buesseler, K. O., Antia, A. N., Chen, M., Fowler, S. W., Gardner, W. D., Gustafsson, O., et al. (2007), An assessment of the use of sediment traps for estimating upper ocean particle fluxes, J. Mar. Res., 65, 345-416.

Checkley D. M., and C. A. Miller (1989), Nitrogen isotope fractionation by oceanic zooplankton, Deep-Sea Res I, 36, 1449-1456.

Dore J. E., J. R. Brum, L. M. Tupas, and D. M. Karl (2002), Seasonal and interannual variability in sources of nitrogen supporting export in the oligotrophic subtropical North Pacific Ocean, Limnol. Oceanogr., 47, 1595-1607.

Dore J. E., R. M. Letelier, M. J. Church, R. Lukas, and D. M. Karl (2008), Summer phytoplankton blooms in the oligotrophic North Pacific Subtropical Gyre: Historical perspective and recent observations, Prog. Oceanogr., 76, 2-38.

Emerson S., R., and J. I. Hedges (2008), Chemical Oceanography and the Marine Carbon Cycle, 375 pp., Cambridge Univ. Press, Cambridge, U. K., doi:10.1017/CBO9780511793202.

Emerson S., P. Quay, D. Karl, C. Winn, L. Tupas, and M. Landry (1997), Experimental determination of the organic carbon flux from open-ocean surface waters, Nature, 389, 951-954.

Eppley R. W., and W. H. Thomas (1969), Comparison of half-saturation constants for growth and nitrate uptake of marine phytoplankton 2, J. Phycol., 5, 375-379.

Fawcett S. E., M. W. Lomas, J. R. Casey, B. B.Ward, and D. M. Sigman (2011), Assimilation of upwelled nitrate by small eukaryotes in the Sargasso Sea, Nat. Geosci., 4, 717-722.

Fawcett S. E., M. W. Lomas, B. B. Ward, and D. M. Sigman (2014), The counterintuitive effect of summer-to-fall mixed layer deepening on eukaryotic new production in the Sargasso Sea, Glob. Biogeochem. Cycles, 28, 86-102.

Fischer G., and G. Karakas (2009), Sinking rates and ballast composition of particles in the Atlantic Ocean: implications for the organic carbon fluxes to the deep ocean, Biogeosciences, 6, 85-102.

Fujiki T., T. Hosaka, H. Kimoto, T. Ishimaru, and T. Saino (2008), In situ observation of phytoplankton productivity by an underwater profiling buoy system: use of fast repetition rate fluorometry, Mar. Ecol. Prog. Ser., 353, 81-88.

Fujiki T., K. Sasaoka, K. Matsumoto, M. Wakita, and Y. Mino (2016), Seasonal variability of phytoplankton community structure in the subtropical western North Pacific, J. Oceanogr., 72, 343-358. 
Fujiki T., R. Inoue, K. Matsumoto, M. C. Honda, M. Wakita, Y. Mino, C. Sukigara, and O. Abe (2019), Time-series observations of photosynthetic oxygen production in the subtropical western North Pacific by an underwater profiling buoy system, Limnol. Oceanogr., https://doi.org/10.1002/lno.11372.

Gattuso J.-P., M. Pichon, and M. Frankignoulle (1995), Biological control of air-sea $\mathrm{CO}_{2}$ fluxes: Effect of photosynthetic and calcifying marine organisms and ecosystems, Mar. Ecol. Prog. Ser., 129, 307-312.

Guidi L. P. H. R. Calil, S. Duhamel, K. M. Björkman, S. C. Doney, G. A. Jackson, et al. (2012), Does eddy-eddy interaction control surface phytoplankton distribution and carbon export in the North Pacific Subtropical Gyre?, J. Geophys. Res., 117, G02024, https://doi: 10.1029/2012JG001984.

Haidar A. T., H. R. Thierstein, and W. G. Deuser (2000), Calcareous phytoplankton standing stocks, fluxes and accumulation in Holocene sediments off Bermuda (N. Atlantic), Deep-Sea Res. II, 47, 1907-1938.

Hanawa K., T. Watanabe, N. Iwasaka, T. Suga, and Y. Toba (1988), Surface thermal conditions in the western North Pacific during the ENSO events, J. Meteor. Soc. Japan, 66, 445456.

Honda M. C., M. Kusakabe, S. Nakabayashi, S. J. Manganini, and S. Honjo (1997), Change in $\mathrm{pCO}_{2}$ through biological activity in the marginal seas of the western North Pacific: the efficiency of the biological pump estimated by a sediment trap experiment, $J$. Oceanogr. 53, 645-662.

Honda M. C., H. Kawakami, S. Watanabe, and T. Saino (2013), Concentration and vertical flux of Fukushima-derived radiocesium in sinking particles from two sites in the Northwestern Pacific Ocean, Biogeosciences, 10, 3525-3534.

Honda M. C., H. Kawakami, K. Matsumoto, M. Wakita, T. Fujiki, Y. Mino, C. Sukigara, T. Kobari, M. Uchimiya, R. Kaneko, and T. Saino (2015), Comparison of sinking particles in the upper $200 \mathrm{~m}$ between subarctic station K2 and subtropical station S1 based on drifting sediment trap experiments, J. Oceanogr., 72, 373-386.

Honda M. C., M., M. Wakita, K. Matsumoto, T. Fujiki, E. Siswanto, K. Sasaoka, et al., (2017), Comparison of carbon cycle between the western Pacific subarctic and subtropical time-series stations: highlights of the K2S1 project, J. Oceanogr., 73, 647-667.

Honda M. C., Y. Sasai, E. Siswanto, A. Kuwano-Yoshida, H. Aiki, and M. F. Cronin (2018), Impact of cyclonic eddies and typhoons on biogeochemistry in the oligotrophic ocean based on biogeochemical/physical/ meteorological time-series at station KEO, Prog. Earth Planet. Sci., 5, 42, https://doi: 10.1186/s40645-018-0196-3.

Honjo S. (1997), The rain of ocean particles and Earth's carbon cycle, Oceanus, 40, 4-8.

Hori M. E., and H. Ueda (2006), Impact of global warming on the East Asian winter monsoon as revealed by nine coupled atmosphere-ocean GCMs, Geophys. Res. Lett., 33, L03713, https://doi:10.1029/2005GL024961.

Iglesias-Rodríguez M. D., C. W. Brown, S. C. Doney, J. Kleypas, D. Kolber, Z. Kolber, P. K. Hayes, and P. G. Falkowski (2002), Representing key phytoplankton functional groups in ocean carbon cycle models: Coccolithophorids, Global Biogeochem. Cycles, 16, 1100, https://doi:10.1029/2001GB001454. 
Inoue R., and S. Kouketsu (2016), Physical oceanographic conditions around the S1 mooring site, J. Oceanogr. 72, 453-464.

Inoue R., M. C. Honda, T. Fujiki, K. Matsumoto, S. Kouketsu, T. Suga, and T. Saino (2016), Western North Pacific Integrated Physical-Biogeochemical Ocean Observation Experiment (INBOX): part 2. Biogeochemical responses to eddies and typhoons revealed from shipboard measurements and the S1 biogeochemical moorings during S1-INBOX, J. Mar. Res., 74, 71-99.

Kaiser J., M. Hastings, B. Houlton, T. Röckmann, and D. Sigman (2007), Triple oxygen isotope analysis of nitrate using the denitrifier method and thermal decomposition of $\mathrm{N}_{2} \mathrm{O}$, Anal. Chem., 79, 599-607.

Karl D. M., and R. Lukas (1996), The Hawaii Ocean Time-series (HOT) program: Background, rationale and field implementation, Deep-Sea Res. II, 48, 129-156.

Karl D. M., M. J. Church, R. M. Letelier, and C. Mahaffey (2012), Predictable and efficient carbon sequestration in the North Pacific Ocean supported by symbiotic nitrogen fixation, Proc. Natl. Acad. Sci. U.S.A., 109, 1842-1849, doi:10.1073/pnas.1120312109.

Khatiwala S., T. Tanhua, S. Mikaloff Fletcher, M. Gerber, S. C. Doney, H. D. Graven, N. Gruber, G. A. McKinley, A. Murata, A. F. Rios, and C. L. Sabine (2013), Global ocean storage of anthropogenic carbon, Biogeosciences, 10, 2169-2191.

Kitajima S., K. Furuya, F. Hashihama, and S. Takeda (2009), Latitudinal distribution of diazotrophs and their nitrogen fixation in the tropical and subtropical western North Pacific, Limnol. Oceanogr., 54, 537-547.

Knapp, A. N., D. M. Sigman, and F. Lipschultz (2005), N isotopic composition of dissolved organic nitrogen and nitrate at the Bermuda Atlantic Time-series Study site, Global Biogeochem. Cycles, 19, GB1018, doi:10.1029/2004GB002320.

Knapp A. N., D. M. Sigman, A. B. Kustka, S. A. Sañudo-Wilhelmy, and D. G. Capone (2012), The distinct nitrogen isotopic compositions of low and high molecular weight marine DON, Mar. Chem., 136-137, 24-33.

Kouketsu S., A. Murata, and T. Doi (2013), Decadal changes in dissolved inorganic carbon in the Pacific Ocean, Global Biogeochem. Cycles, 27, 65-76.

Longhurst A.R. (1998), Ecological Geography of the Sea, 398 pp. Academic Press.

Lourey M. J., T. W. Trull, and D. M. Sigman (2003), Sensitivity of $\delta^{15}$ N of nitrate, surface suspended and deep sinking particulate nitrogen to seasonal nitrate depletion in the Southern Ocean, Global Biogeochem. Cycles, 17, 1081, https://doi:10.1029/2002GB001973.

Matsumoto K., O. Abe, T. Fujiki, C. Sukigara, and Y. Mino (2016), Primary productivity at the time-series stations in the northwestern Pacific Ocean: is the subtropical station unproductive?, J. Oceanogr., 72, 359-371.

Margalef R. (1978), Life-forms of phytoplankton as survival alternatives in an unstable environment, Oceanol. Acta, 1, 493-509.

McGillicuddy D. J., L. A. Anderson, N. R. Bates, T. Biddy, K. O. Buesseler, C. A. Carlson, C. S. Davis, C. Ewart, P. G. Falkowski, S. A. Goldthwait, D. A. Hansell, W. J. Jenkins, R. Johnson, V. K. Kosnyrev, J. R. Ledwell, Q. P. Li, D. A. Siegel, and D. K. Steinberg 
(2007), Eddy/wind interaction stimulate extraordinary mid-ocean plankton blooms, Science, 316, 1021-1026.

Minagawa M., and E. Wada (1986), Nitrogen isotope ratios of red tide organisms in the East China Sea: A characterization of biological nitrogen fixation, Mar. Chem. 19, 245-259.

Mino Y., T. Saino, K. Suzuki, and E. Marañón (2002), Isotopic composition of suspended particulate nitrogen $\left(\delta^{15} \mathrm{Nsus}\right)$ in surface waters of the Atlantic Ocean from $50^{\circ} \mathrm{N}$ to $50^{\circ} \mathrm{S}, \quad$ Global Biogeochem. Cycles, 16, 7-1-7-9. https://doi.org/10.1029/2001GB001635.

Mino Y., C. Sukigara, H. Kawakami, M. C. Honda, K. Matsumoto, M. Wakita, M. Kitamura, T. Fujiki, K. Sasaoka, O. Abe, J. Kaiser, and T. Saino (2016), Seasonal variations in the nitrogen isotopic composition of settling particles at station K2 in the western subarctic North Pacific, J. Oceanogr., 72, 819-836.

Miyake Y., and E. Wada (1967), The abundance ratio of ${ }^{15} \mathrm{~N} /{ }^{14} \mathrm{~N}$ in marine environments, Rec. Oceanogr. Works Jpn, 9, 37-53.

Montoya J. P., E. J. Carpenter, and D. G. Capone (2002), Nitrogen fixation and nitrogen isotope abundances in zooplankton of the oligotrophic North Atlantic, Limnol. Oceanogr., 47, $1617-1628$.

Mouriño-Carballido B., and S. Neuer (2008), Regional Differences in the Role of Eddy Pumping in the North Atlantic Subtropical Gyre: Historical Conundrums Revisited, Oceanography, 21, 52-61.

Neuer S., A. Cianca, P. Helmke, T. Freudenthal, R. Davenport, H. Megggers, M. Knoll, J. M. Santana-Casiano, M. González-Dávila, M. Rueda, and O. Llinás (2007), Biogeochemistry and hydrography in the eastern subtropical North Atlantic gyre. Results from the European time-series station ESTOC, Prog. Oceanogr., 72, 1-29.

Nicholson D., S. Emerson, and C. C. Eriksen (2008), Net community production in the deep euphotic zone of the subtropical North Pacific gyre from glider surveys, Limnol. Oceanogr., 53, 2226-2236.

Noh Y., and S. Nakada (2010), Examination of the particle flux from the convective mixed layer by large eddy simulation, J. Geophys. Res., 115, C05007, https://doi:10.1029/2009JC005669.

Oka E., K. Toyama, and T. Suga (2009), Subduction of North Pacific central mode water associated with subsurface mesoscale eddy, Geophys. Res. Lett., 36, L08607, https://doi:10.1029/2009GL037540.

Paasche E. (2002), A review of the coccolithophorid Emiliania huxleyi (Prymnesiophyceae), with particular reference to growth, coccolith formation, and calcificationphotosynthesis interactions, Phycologia, 40, 503-529.

Polovina, J. J., E.A. Howell, and M. Abecassis (2008), Ocean's least productive waters are expanding, Geophys. Res. Lett., 35, https://doi:10.1029/2007GL031745.

Poulton A. J., R. Sanders, P. M. Holligan, M. C. Stinchcombe, T. Adey, L. Brown, and K. Chamberlain (2006), Phytoplankton mineralisation in the tropical and subtropical Atlantic Ocean, Global Biogeochem. Cycles, 20, GB4002, https://doi:10.1029/2006GB002712. 
Qiu B., and S. Chen (2010), Interannual variability of the North Pacific Subtropical Countercurrent and its associated mesoscale eddy field, J. Phys. Oceanogr., 40, 213225.

Qiu B., P. Hacker, S. Chen, K. A. Donohue, D. R. Watts, H. Mitsudera, N. G. Hogg, and S. R. Jayne (2006), Observation of the subtropical mode water evolution from the Kuroshio extension system study, J. Phys. Oceanogr., 36, 457-473.

Orcutt, K. M., F. Lipschultz, K. Gundersen, R. Arimoto, A. F. Michaels, A. H. Knap, and J. R. Gallon (2001), A seasonal study of the significance of N2 fixation by Trichodesmium spp. at the Bermuda Atlantic Time- series Study (BATS) site, Deep Sea Res., Part II, $48,1583-1608$.

Riegman R., W. Stolte, A. A. M. Noordeloos, and D. Slezak (2000), Nutrient uptake and alkaline phosphatase (EC 3:1:3:1) activity of Emiliania huxleyi (Prymnesiophyceae) during growth under $\mathrm{N}$ and $\mathrm{P}$ limitation in continuous cultures, J. Phycol., 36, 87-96.

Riser S. C., and K. S. Johnson (2008), Net production of oxygen in the subtropical ocean, Nature, 451, 323-325.

Sato M., F. Hashihama, S. Kitajima, S. Takeda, and K. Furuya (2010), Distribution of nanosized Cyanobacteria in the western and central Pacific Ocean, Aquat. Microb. Ecol., 59, 273-282.

Schmidt K., C. L. De La Rocha, M. Gallinari, and G. Cortese (2014), Not all calcite ballast is created equal: differing effects of foraminiferan and coccolith calcite on the formation and sinking of aggregates, Biogeosciences, 11, 135-145.

Shiozaki T., K. Furuya, T. Kodama, S. Kitajima, S. Takeda, T. Takemura, and J. Kanda (2010), New estimation of $\mathrm{N}_{2}$ fixation in the western and central Pacific Ocean and its marginal seas. Global Biogeochem. Cycles, 24, GB1015, https://doi:10.1029/2009GB003620.

Shutler J. D., P. E. Land, C. W. Brown, H. S. Findlay, C. J. Donlon, M. Medland, R. Snooke, and J. C. Blackford (2013), Coccolithophore surface distributions in the North Atlantic and their modulation of the air-sea flux of $\mathrm{CO}_{2}$ from 10 years of satellite Earth observation data, Biogeosciences, 10, 2699-2709.

Siegel D. A. and W.G. Deuser (1997), Trajectories of sinking particles in the Sargasso Sea: modeling of statistical funnels above deep-ocean sediment traps, Deep-Sea Res., 44, 1519-1541.

Sigman D. M., K. L. Casciotti, M. Andreani, C. Barford, M. Galanter, and J. K. Böhlke (2001), A bacterial method for the nitrogen isotopic analysis of nitrate in seawater and freshwater, Anal. Chem., 73, 4145-4153.

Siswanto E., K. Matsumoto, M. C. Honda, T. Fujiki, K. Sasaoka, and T. Saino (2015), Reappraisal of meridional differences of factors controlling phytoplankton biomass and initial increase preceding seasonal bloom in the northwestern Pacific Ocean, Remote Sens. Environ., 159, 44-56.

Steinberg D. K., C.A. Carlson, N.R. Bates, R.J. Johnson, A.F. Michaels, and A.H. Knap (2001), Overview of the US JGOFS Bermuda Atlantic Time-series Study (BATS): A decadescale look at ocean biology and biogeochemistry, Deep-Sea Res. II, 48, 1405-1447.

Sukigara C., T. Suga, K. Toyama, and E. Oka (2014), Biogeochemical responses associated with the passage of a cyclonic eddy based on shipboard observations in the western North Pacific, J. Oceanogr., 70, 435-445. 
Sukigara C., Y. Mino, H. Kawakami, M. C. Honda, T. Fujiki, K. Matsumoto, M. Wakita, and T. Saino (2019), Sinking dynamics of particulate matter in the subarctic and subtropical regions of the western North Pacific, Deep-Sea Res. I, 144, 17-27.

Wakita M., M. C. Honda, K. Matsumoto, T. Fujiki, H. Kawakami, S. Yasunaka, Y. Sasai, C. Sukigara, M. Uchimiya, M. Kitamura, Y. Mino, A. Nagano, N. Usui, S. Watanabe, and T. Saino (2016), Biological organic carbon export estimated from carbon budget in the surface water of western subarctic and subtropical North Pacific Ocean, J. Oceanogr., $72,665-685$.

Wu J., S. E. Calvert, C. S. Wong, and F. A. Whitney (1999), Carbon and nitrogen isotopic composition of sedimenting particulate material at Station Papa in the subarctic northeast Pacific, Deep-Sea Res. II, 46, 2793-2832.

Yoshikawa, C., Y. Yamanaka, and T. Nakatsuka, (2005), An ecosystem model including nitrogen isotopes: Perspectives on a study of the marine nitrogen cycle, J. Oceanogr., 61, 921-942.

Yoshikawa C., A. Makabe, T. Shiozaki, S. Toyoda, O. Yoshida, K. Furuya, and N. Yoshida (2015), Nitrogen isotope ratios of nitrate and $\mathrm{N}^{*}$ anomalies in the subtropical South Pacific, Geochem. Geophy. Geosy., 16, 1439-1448.

Yoshikawa C., A. Makabe, Y. Matsui, T. Nunoura, and N. Ohkouchi (2018), Nitrate isotope distribution in the subarctic and subtropical North Pacific, Geochem. Geophy. Geosy., $19,2212-2224$.

Zehr J. P., J. B. Waterbury, P. J. Turner, J. P. Montoya, E. Omoregie, G. F. Steward, A. Hansen, and D. M. Karl (2001), Unicellular cyanobacteria fix $\mathrm{N}_{2}$ in the subtropical North Pacific Ocean, Nature, 412, 635-638.

Zhang X., J. A. Church, S. M. Platten, and D. Monselesan (2014), Projection of subtropical gyre circulation and associated sea level changes in the Pacific based on CMIP3 climate models, Clim. Dyn., 43, 131-144.

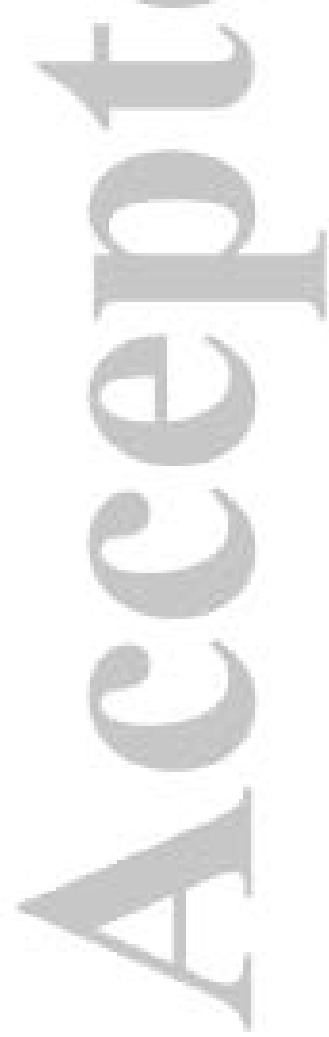


Table 1. Hydrographic and chemical properties and $\delta^{15} \mathrm{~N}$ of particles at $\mathrm{S} 1$ during five repeat cruises. SST indicates sea surface temperature, MLD mixed layer depth, $\delta^{15} \mathrm{~N}$ (SUS) and $\delta^{15} \mathrm{~N}(\mathrm{DST})$ nitrogen isotope composition of particles obtained from water sampling (i.e. suspended particles) and drifting sediment trap experiment (settling ones), respectively. DCM indicates deep chlorophyll maximum that was seen during non-winter cruises.

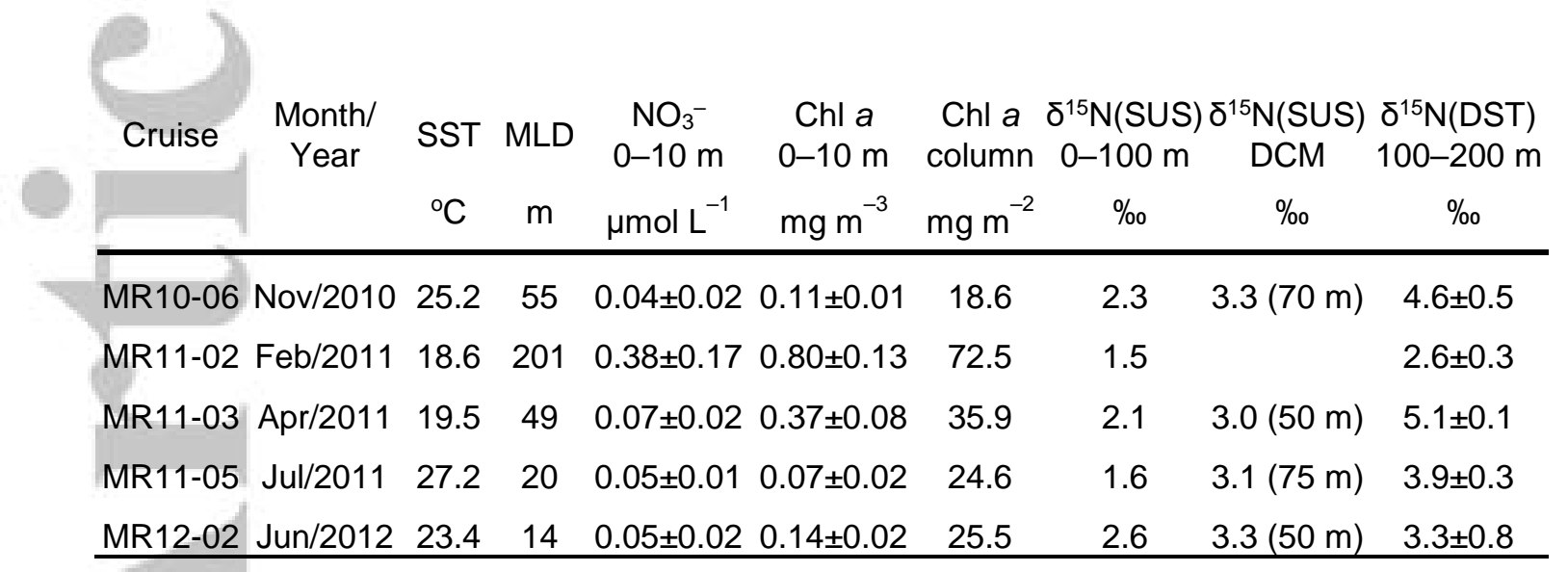

Table 2. Bloom periods during 2010-14 and the period with $\delta^{15} \mathrm{~N}(\mathrm{MST})<4 \%$ in each bloom. Bloom was defined as the time with satellite $\mathrm{Chl} a$ higher than $0.10 \mathrm{mg} \mathrm{m}^{-3}$ which corresponds to $20 \%$ higher than the median during 2010-14. Note that the bloom of a given year starts in December of the previous year, and this also holds for the low $\delta^{15} \mathrm{~N}(\mathrm{MST})$ period in 2012.

\begin{tabular}{lllc} 
Year & Bloom period & Period with $\delta^{15} \mathrm{~N}<4 \%$ & Days with $\delta^{15} \mathrm{~N}<4 \% 0$ \\
\hline 2010 & ${ }^{* * * * *} .^{* * * *}-07$ Jun. 2010 & ${ }^{* * * *} .{ }^{* * * *}-04$ May. 2010 & \\
2011 & 14 Dec. 2010 - 09 Jun. 2011 & 12 Jan. 2011-29 Apr. 2011 & 108 \\
2012 & 21 Dec. 2011- 08 Jun. 2012 & 21 Dec. 2011-10 Apr. 2012 & 112 \\
2013 & 07 Dec. 2012 - 15 Jun. 2013 & 04 Feb. 2013-16 Apr. 2013 & 72 \\
2014 & 17 Dec. 2013-04 Jul. 2014 & 01 Feb. 2014-22 Apr. 2014 & 81 \\
\hline
\end{tabular}


Table 3. Mean total mass flux TMF, organic carbon flux OCF and mass fractions of organic matter $w(\mathrm{OM})$ and calcium carbonate $w\left(\mathrm{CaCO}_{3}\right)$, and $\delta^{15} \mathrm{~N}$ of trapped particles during five MST experiments (Trap-1 to 5). The mean values during periods of bloom and non-bloom in 201014 are also listed. *Exceptionally, two flux peaks were found during the non-bloom period in 2011 (see text).

\begin{tabular}{|c|c|c|c|c|c|c|}
\hline Trap & Period & $\begin{array}{c}\text { TMF } \\
\mathrm{mg} \mathrm{m}^{-2} \mathrm{~d}^{-1} \mathrm{n} \\
\end{array}$ & $\begin{array}{c}\text { OCF } \\
\mathrm{mg} \mathrm{m}^{-2} \mathrm{~d}^{-1}\end{array}$ & $\begin{array}{c}w(\mathrm{OM}) \\
\%\end{array}$ & $\begin{array}{c}w\left(\mathrm{CaCO}_{3}\right) \\
\% \\
\end{array}$ & $\begin{array}{c}\delta^{15} \mathrm{~N}(\mathrm{MST}) \\
\% 0 \\
\end{array}$ \\
\hline Trap-1 & 22 Feb. 2010 - 01 Nov. 2010 & $81 \pm 133$ & $20 \pm 32$ & $59 \pm 14$ & $41 \pm 12$ & $4.5 \pm 0.8$ \\
\hline Trap-2 & 13 Nov. 2010 - 23 Jul. 2011 & $49 \pm 54$ & $8 \pm 4$ & $46 \pm 19$ & $48 \pm 15$ & $4.0 \pm 1.1$ \\
\hline Trap-3 & 30 Jul. 2011 - 30 Jun. 2012 & $110 \pm 62$ & $21 \pm 14$ & $51 \pm 18$ & $44 \pm 15$ & $4.1 \pm 0.7$ \\
\hline Trap-4 & 03 Jul. 2012 - 16 Jul. 2013 & $24 \pm 12$ & $5 \pm 3$ & $53 \pm 11$ & $45 \pm 11$ & $4.5 \pm 0.8$ \\
\hline Trap-5 & 18 Jul. 2013 - 16 Jun. 2014 & $21 \pm 10$ & $4 \pm 2$ & $54 \pm 11$ & $45 \pm 11$ & $4.2 \pm 0.8$ \\
\hline all & & $60 \pm 79$ & $12 \pm 17$ & $52 \pm 15$ & $44 \pm 13$ & $4.2 \pm 0.8$ \\
\hline \multicolumn{7}{|l|}{ Bloom } \\
\hline 2010 & 22 Feb. 2010 - 09 Jun. 2010 & $174 \pm 182$ & $35 \pm 42$ & $50 \pm 16$ & $45 \pm 14$ & $4.3 \pm 1.1$ \\
\hline 2011 & 19 Dec. 2010 - 04 Jun. 2011 & $61 \pm 59$ & $9 \pm 4$ & $46 \pm 19$ & $49 \pm 15$ & $3.6 \pm 0.9$ \\
\hline 2012 & 21 Dec. $2011-28$ May. 2012 & $124 \pm 51$ & $19 \pm 9$ & $40 \pm 12$ & $53 \pm 9$ & $3.8 \pm 0.6$ \\
\hline 2013 & 12 Dec. 2012 - 09 Jun. 2013 & $30 \pm 10$ & $7 \pm 3$ & $54 \pm 12$ & $43 \pm 11$ & $4.2 \pm 1.1$ \\
\hline$\underline{2014}$ & 09 Dec. 2013 - 28 May. 2014 & $25 \pm 10$ & $5 \pm 2$ & $47 \pm 7$ & $51 \pm 7$ & $3.8 \pm 0.7$ \\
\hline all & & $80 \pm 94$ & $14 \pm 20$ & $47 \pm 14$ & $49 \pm 12$ & $3.9 \pm 0.9$ \\
\hline \multicolumn{7}{|c|}{ Non-bloom } \\
\hline 2010 & 10 Jun. $2010-18$ Dec. 2010 & $22 \pm 11$ & $7 \pm 3$ & $61 \pm 7$ & $36 \pm 6$ & $4.8 \pm 0.4$ \\
\hline 2011 & 05 Jun. 2011 - 20 Dec. 2011 & $77 \pm 75^{\star}$ & $21 \pm 19^{*}$ & $71 \pm 5$ & $28 \pm 5$ & $4.7 \pm 0.6$ \\
\hline 2012 & 29 May. 2012 - 11 Dec. 2012 & $24 \pm 19$ & $5 \pm 4$ & $52 \pm 10$ & $46 \pm 10$ & $4.8 \pm 0.3$ \\
\hline $\begin{array}{l}2013 \\
2014 \\
\end{array}$ & 10 Jun. 2013 - 08 Dec. 2013 & $18 \pm 12$ & $4 \pm 1$ & $61 \pm 14$ & $38 \pm 13$ & $4.5 \pm 0.5$ \\
\hline all & & $34 \pm 43$ & $9 \pm 12$ & $61 \pm 11$ & $38 \pm 11$ & $4.8 \pm 0.5$ \\
\hline
\end{tabular}


Table 4. Flux weighted average chemical compositions of MST particles during the period with low $\mathrm{PN}-\delta^{15} \mathrm{~N}\left(<4 \%\right.$ \%). $w(\mathrm{OM}), w($ opal $), w\left(\mathrm{CaCO}_{3}\right)$, and $w(\mathrm{LM})$ are the mass fractions of organic matter, opal, calcium carbonate, and lithogenic materials, respectively. $R$ (POC:PIC) is the mole ratio of organic carbon to inorganic carbon.

\begin{tabular}{|c|c|c|c|c|c|c|}
\hline & Period of $\delta^{15} N(M S T)<4 \%$ & $\begin{array}{c}w(\mathrm{OM}) \\
\% \\
\end{array}$ & $\begin{array}{c}w \text { (opal) } \\
\% \\
\end{array}$ & $\begin{array}{c}w\left(\mathrm{CaCO}_{3}\right) \\
\% \\
\end{array}$ & $\begin{array}{c}w(\mathrm{LM}) \\
\% \\
\end{array}$ & $\begin{array}{c}R(\mathrm{POC}: \mathrm{PIC}) \\
\mathrm{mol} \mathrm{mol}^{-1}\end{array}$ \\
\hline \multicolumn{7}{|c|}{ winter/spring } \\
\hline 2011 & 12 Jan. 2011 - 24 Apr. 2011 & 32.7 & 5.6 & 58.3 & 3.4 & 1.6 \\
\hline 2012 & 21 Dec. 2011 - 10 Apr. 2012 & 37.2 & 6.0 & 54.1 & 2.7 & 2.0 \\
\hline 2013 & 04 Feb. 2013 - 16 Apr. 2013 & 50.3 & 2.3 & 45.7 & 1.7 & 3.2 \\
\hline 2014 & 01 Feb. $2014-22$ Apr. 2014 & 47.6 & 0.6 & 50.9 & 1.0 & 2.7 \\
\hline \multicolumn{7}{|c|}{ summer } \\
\hline 2011 & 15 Aug. $2011-15$ Sep. 2011 & 73.9 & 1.0 & 24.7 & 0.4 & 8.7 \\
\hline
\end{tabular}

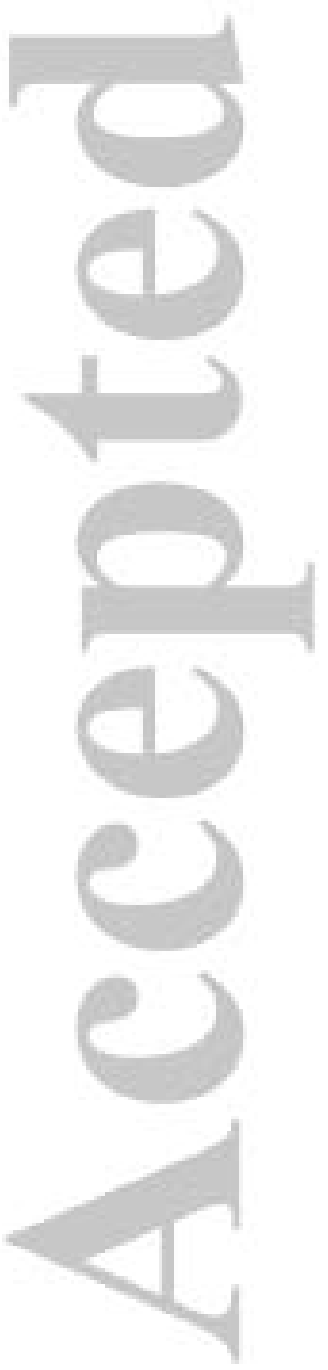




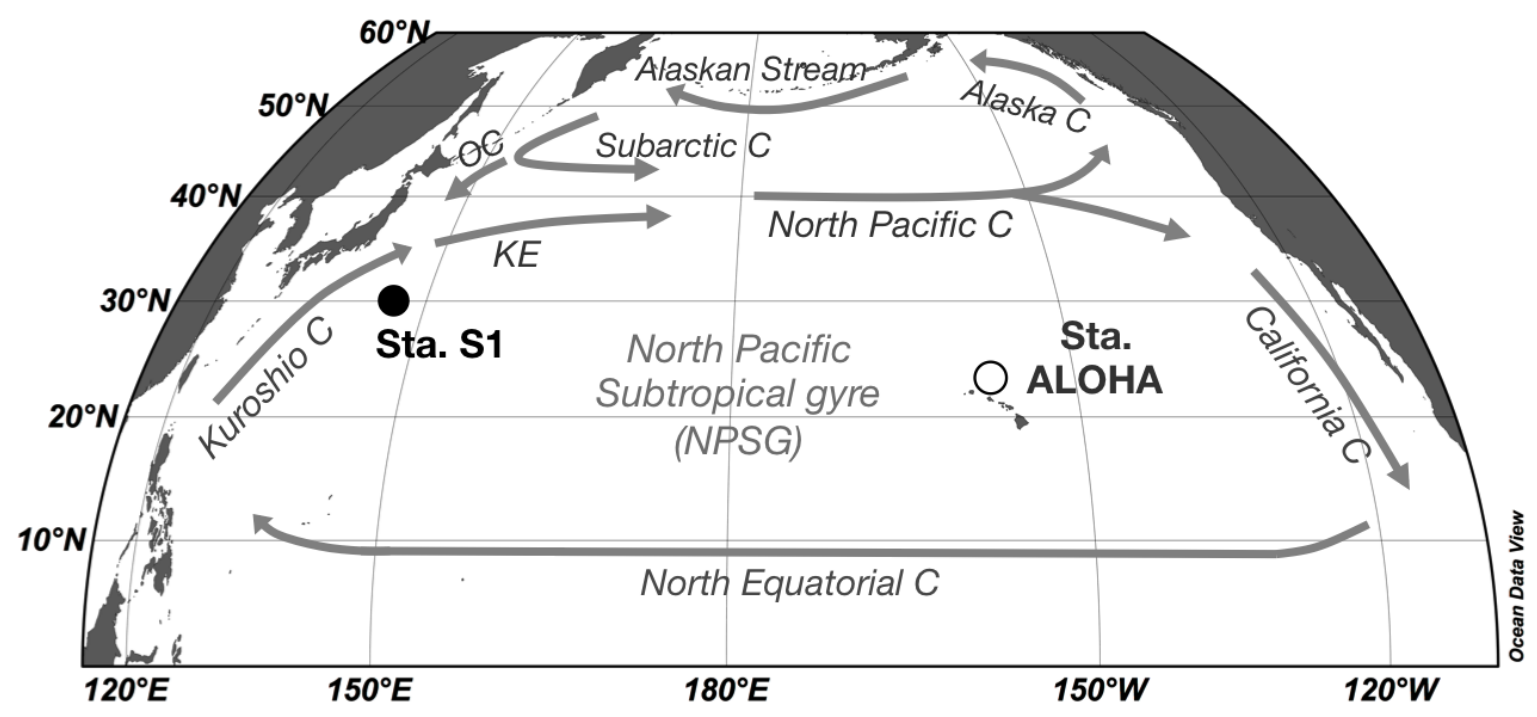

Figure 1. Locations of time-series Sta. S1 $\left(30^{\circ} \mathrm{N}, 145^{\circ} \mathrm{E}\right)$ and Sta. ALOHA $\left(22^{\circ} 45^{\prime} \mathrm{N}, 158^{\circ} \mathrm{W}\right)$ in the North Pacific subtropical gyre, bounded by prevailing currents (grey arrows). $K E$ and $O C$ indicates Kuroshio extension and Oyashio current, respectively. 


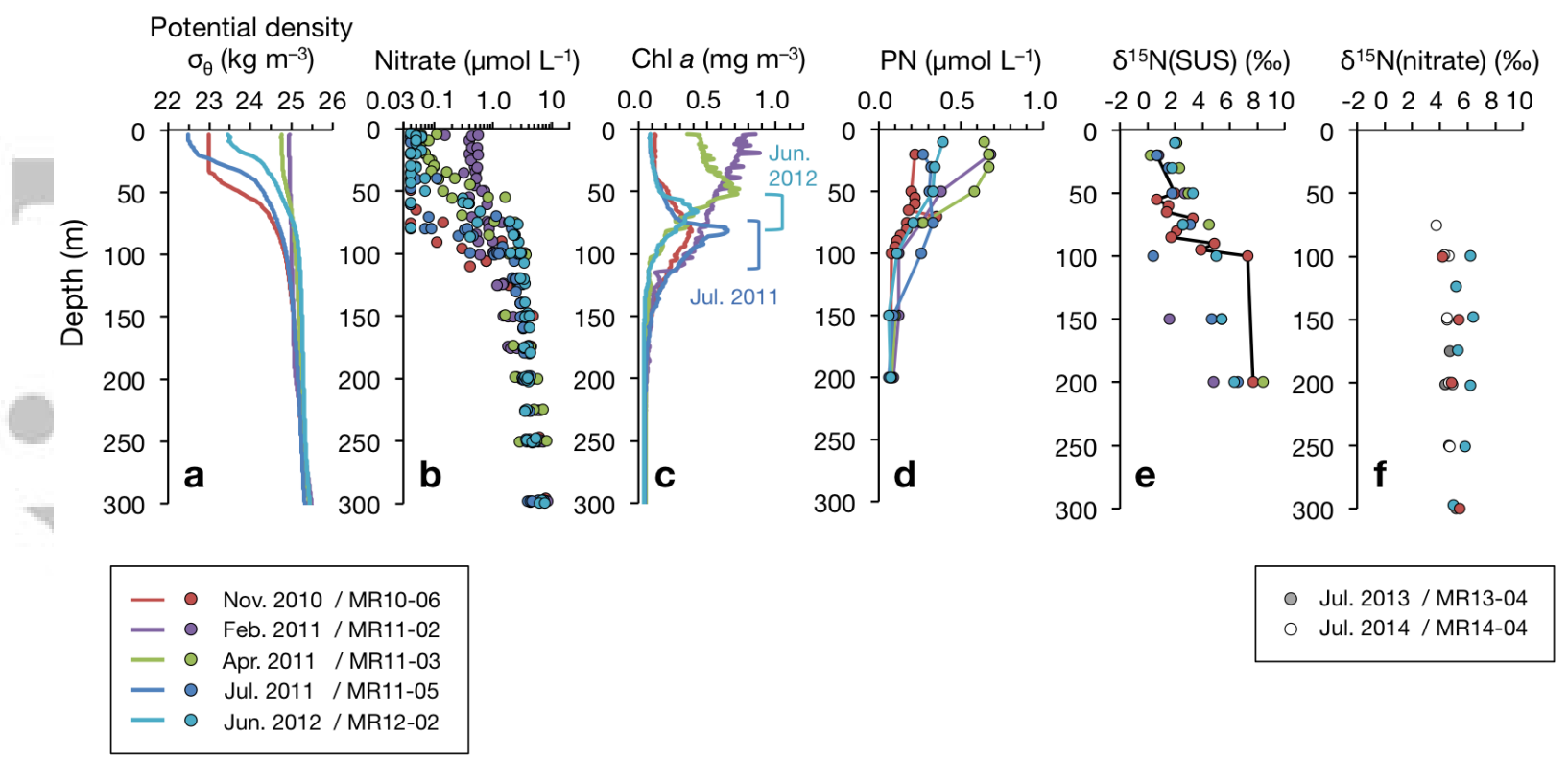

Figure 2. Vertical profiles of parameters in the upper water column at station S1 observed during five cruises in 2010-12, MR10-06 (Nov. 2010), MR11-02 (Feb. 2011), MR11-03 (Apr. 2011), MR11-05 (Jul. 2011), and MR12-02 (Jun. 2012). (a) potential density anomaly, $\sigma_{\vartheta}$, (b) nitrate, (c) Chl $a$, (d) suspended particulate nitrogen concentration, (e) $\delta^{15} \mathrm{~N}$ of suspended particles, $\delta^{15} \mathrm{~N}(\mathrm{SUS})$, and (f) nitrate $\delta^{15} \mathrm{~N}$. For nitrate $\delta^{15} \mathrm{~N}$, data at S1 in July 2013 and data at the near S1 station (410 km east of S1) in July 2014 (from Yoshikawa et al. [2018]) were added in panel $\mathrm{f}$. Note that nitrate $\delta^{15} \mathrm{~N}$ in June 2012 were significantly higher among them (homoscedastic Student's $t$-test; $p<0.001$ ). Black solid line in panel e indicates the vertical increase of $\delta^{15} \mathrm{~N}$ (SUS) observed during MR10-06 when data were obtained in $5 \mathrm{~m}$ interval at 50-100 $\mathrm{m}$. Position of DCMs (here defined as >0.25 $\mathrm{mg} \mathrm{m}^{-3}$ ) during MR11-05 and MR12-02 were noted in panel c. 


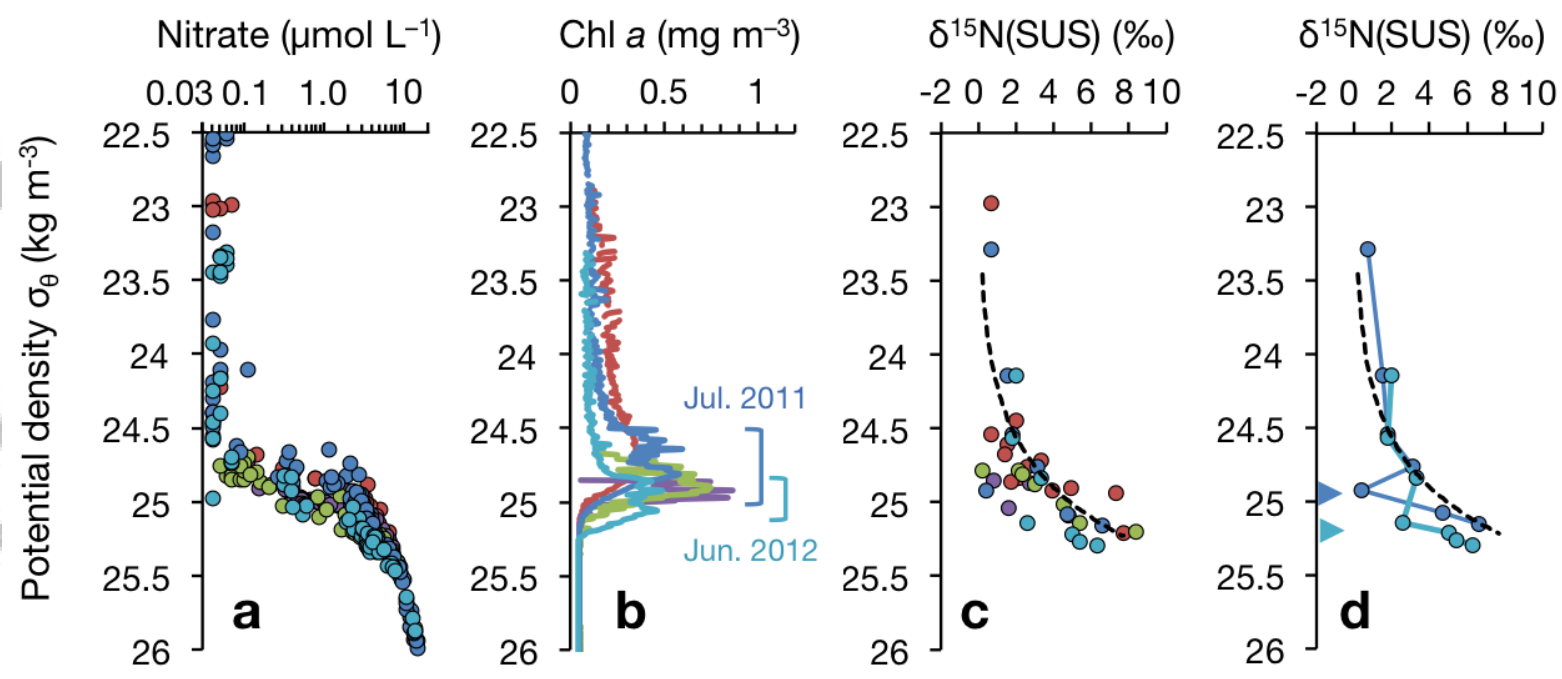

Figure 3. Vertical profiles of (a) nitrate, (b) Chl $a$ concentrations, (c, d) $\delta^{15} \mathrm{~N}(\mathrm{SUS})$ with respect to sigma theta. Only two profiles from summer cruises, MR11-05 and MR12-02 are plotted in panel d. Symbols are the same as those in Figure 2. Dashed line in panels c and d indicates the vertical increase of $\delta^{15} \mathrm{~N}$ (SUS) sigma theta during MR10-06. Triangles in blue and cyan in panel d indicate slight $\delta^{15} \mathrm{~N}$ (SUS) drops in lower part of DCMs found during MR11-05 and MR12-02, respectively.

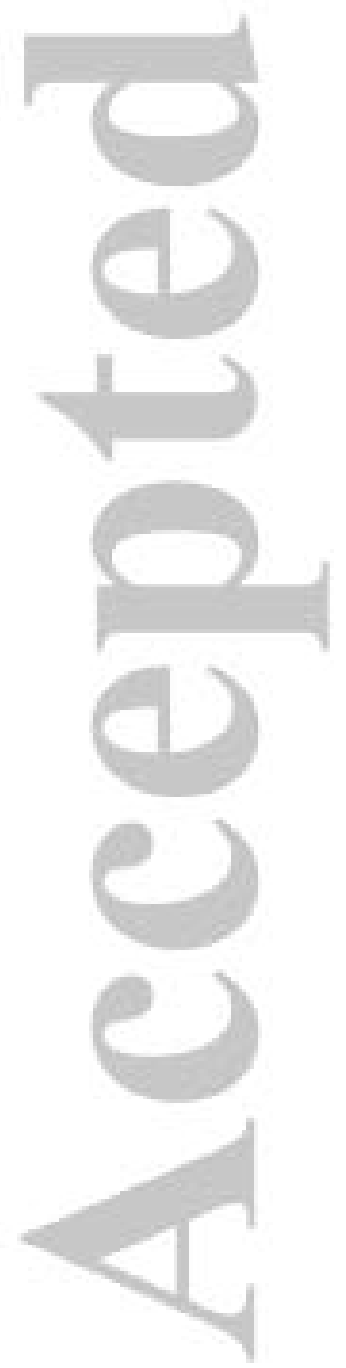




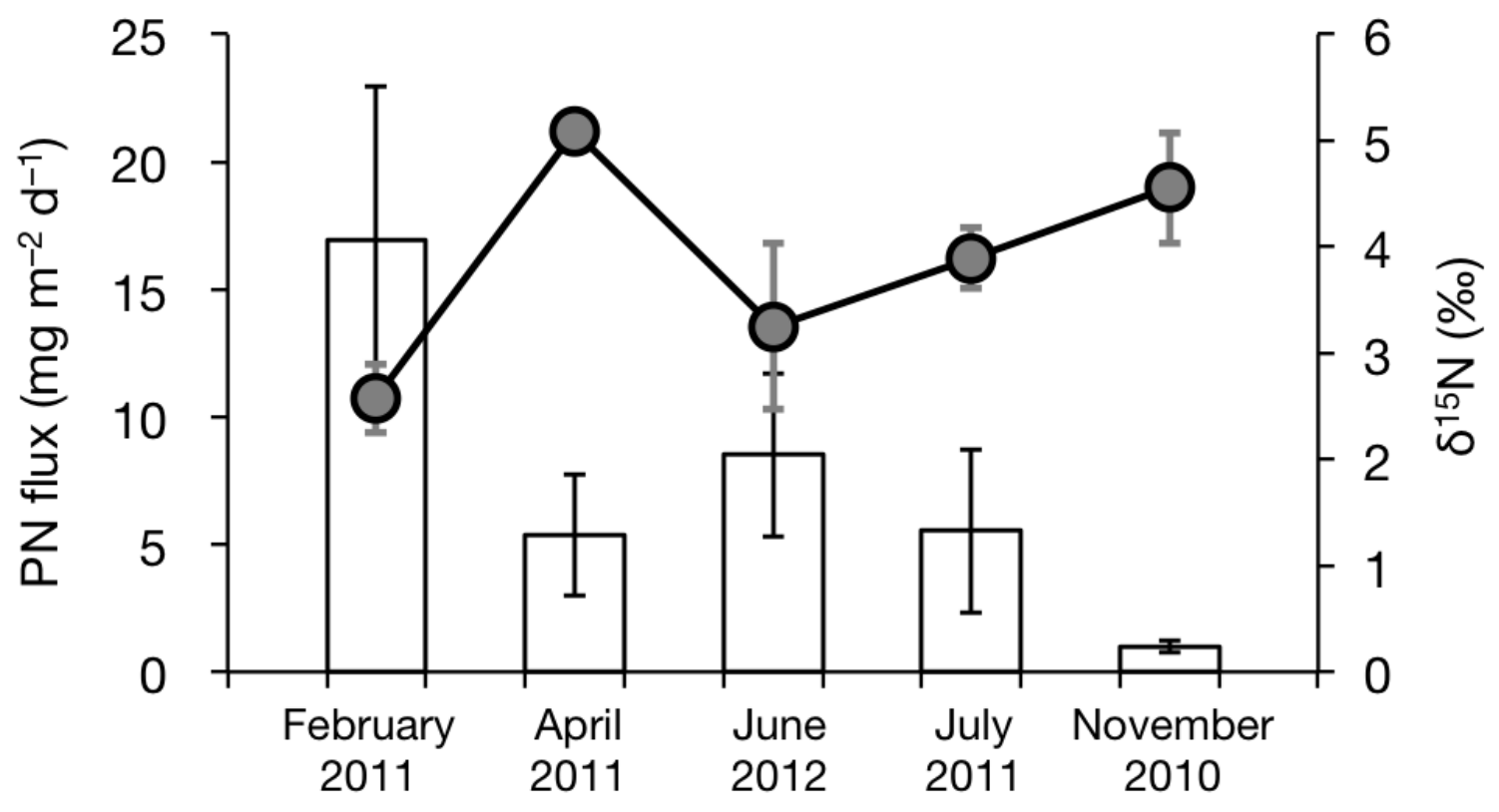

Figure 4. Mean particulate nitrogen flux (bars) and $\delta^{15} \mathrm{~N}$ of the DST particles (circles) obtained during cruises in 2010-12. DST particles were collected at 100, 150, and $200 \mathrm{~m}$ for 3-4 days by using free-drifting array with cylindrical traps. 

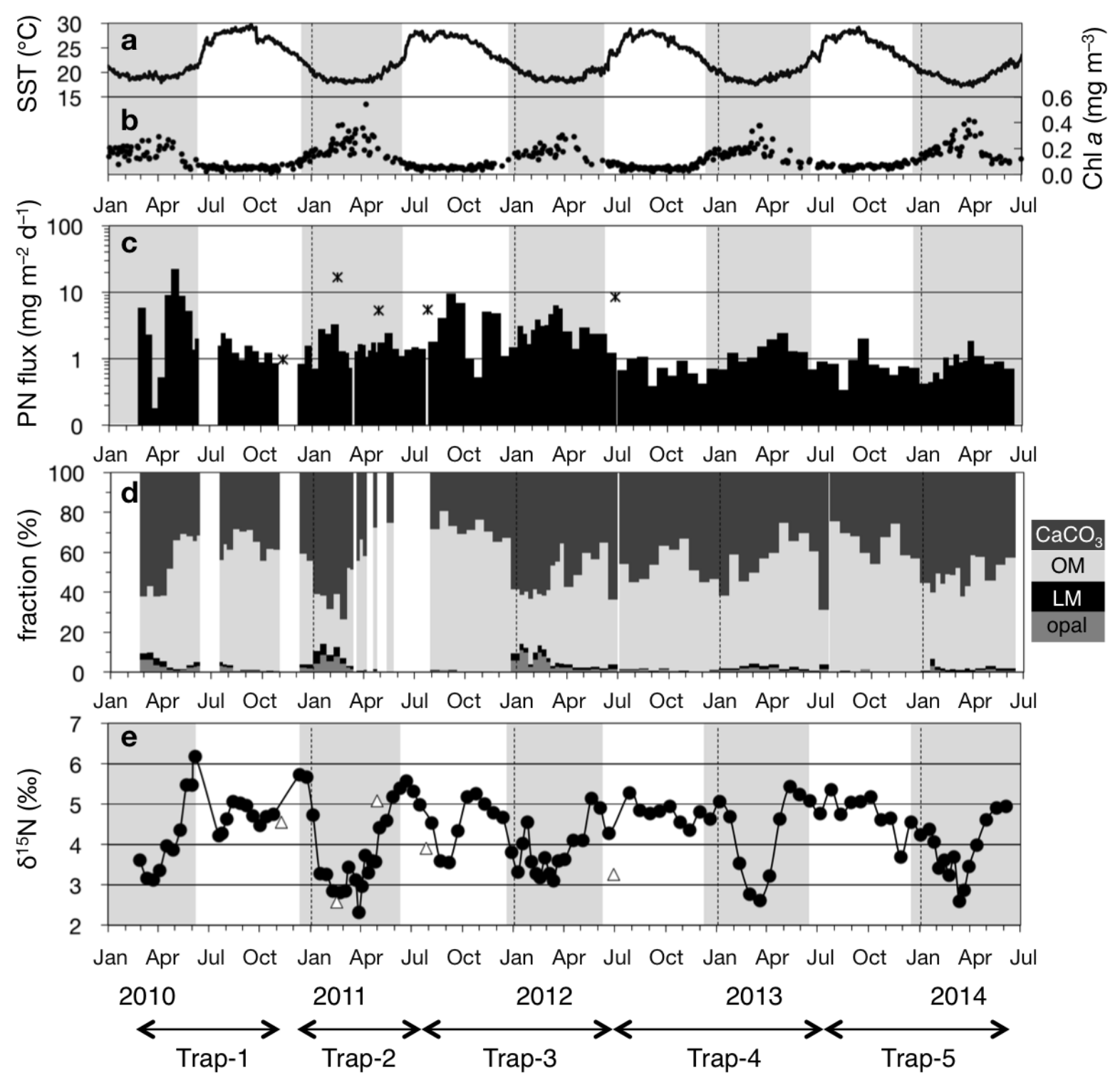

Figure 5. Time series data of satellite based (a) SST, (b) surface Chl $a$ concentration, and moored sediment trap-based (c) particulate nitrogen (PN) flux (note: vertical axis is logarithmic scale), (d) chemical composition (mass fractions of calcium carbonate, organic matter, lithogenic material, and opal) and (e) $\delta^{15} \mathrm{~N}$ of MST particles at $200 \mathrm{~m}$ in S1 during 2010-14. $\mathrm{PN}$ flux and $\mathrm{PN}-\delta^{15} \mathrm{~N}$ obtained from short-term DST experiments during cruises, shown in Figure 4, were also plotted as asterisks and open triangles in panel c and e, respectively. The bloom period in winter/spring is shaded in figures a-c, e (see text). Trap 1-5 indicates the period of five MST experiments. 

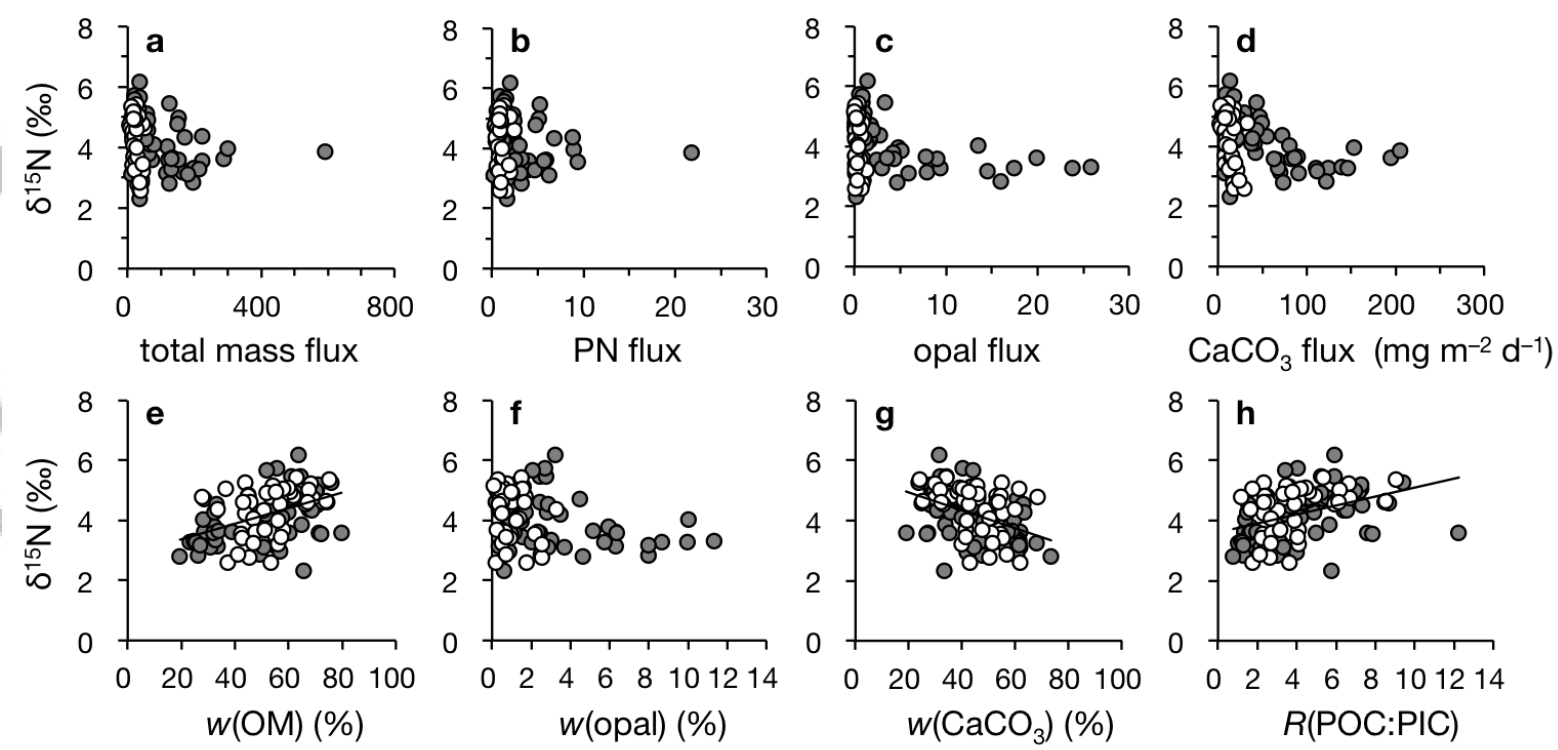

Figure 6. Scatter plots of $\mathrm{PN}-\delta^{15} \mathrm{~N}$ vs. particle fluxes (a-d) and chemical compositions $(\mathrm{e}-\mathrm{h})$ for MST particles. Flux is (a) total mass, (b) particulate nitrogen, (c) opal, and (d) $\mathrm{CaCO}_{3}$. Composition is the mass fraction of (e) organic matter, $w(\mathrm{OM})$, (f) opal, $w(\mathrm{opal}),(\mathrm{g})$ calcium carbonate, $w\left(\mathrm{CaCO}_{3}\right)$, and $(\mathrm{h})$ the mole ratio of organic carbon to inorganic carbon of particles, $R$ (POC:PIC). Grey and white symbols represent data from MST experiments T1-3 and T4-5, respectively. The solid line in panels $\mathrm{e}, \mathrm{g}$, and $\mathrm{h}$ indicates a linear regression with $w(\mathrm{OM})$ $(r=0.46, p<0.001), w\left(\mathrm{CaCO}_{3}\right) \quad(r=-0.44, p<0.001)$, and $R$ (POC:PIC) $(r=0.41 p<0.001)$, respectively, based on all experimental data. 


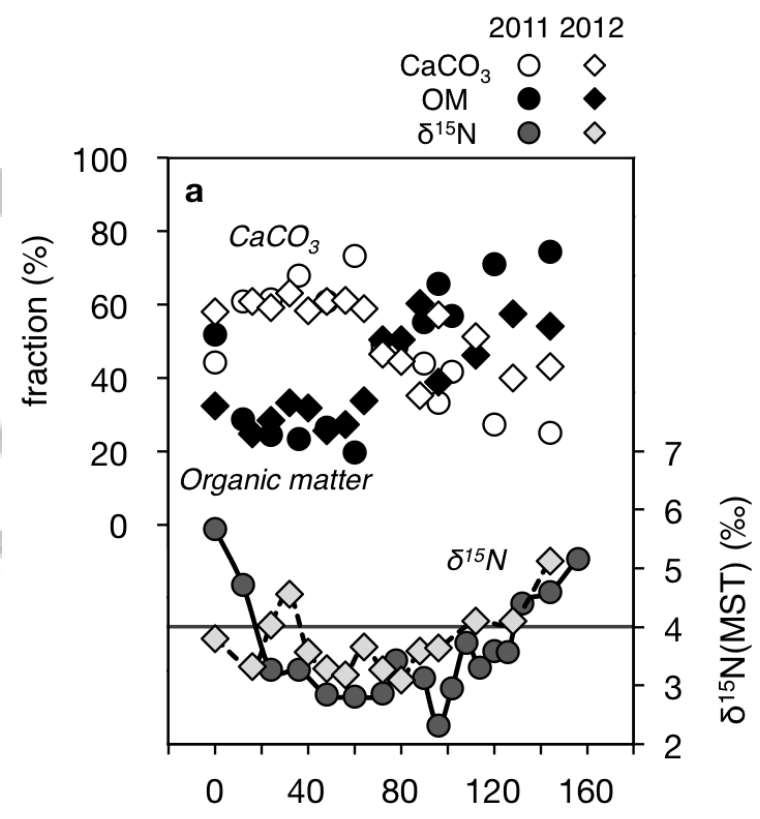

Days from bloom initiation

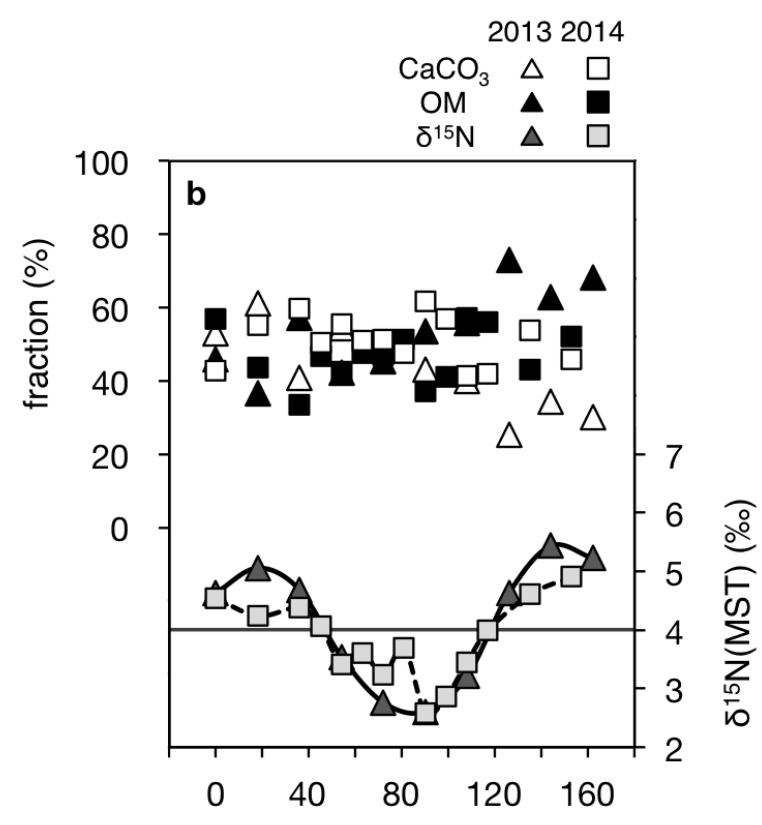

Days from bloom initiation

Figure 7. Temporal variations in mass fractions of organic matter (black) and $\mathrm{CaCO}_{3}$ (white), and those in $\delta^{15} \mathrm{~N}$ (gray) of MST particles collected during winter/spring blooms in (a) 20112012, and (b) 2013-2014. The bloom initiation in each year was described in Table 2. 

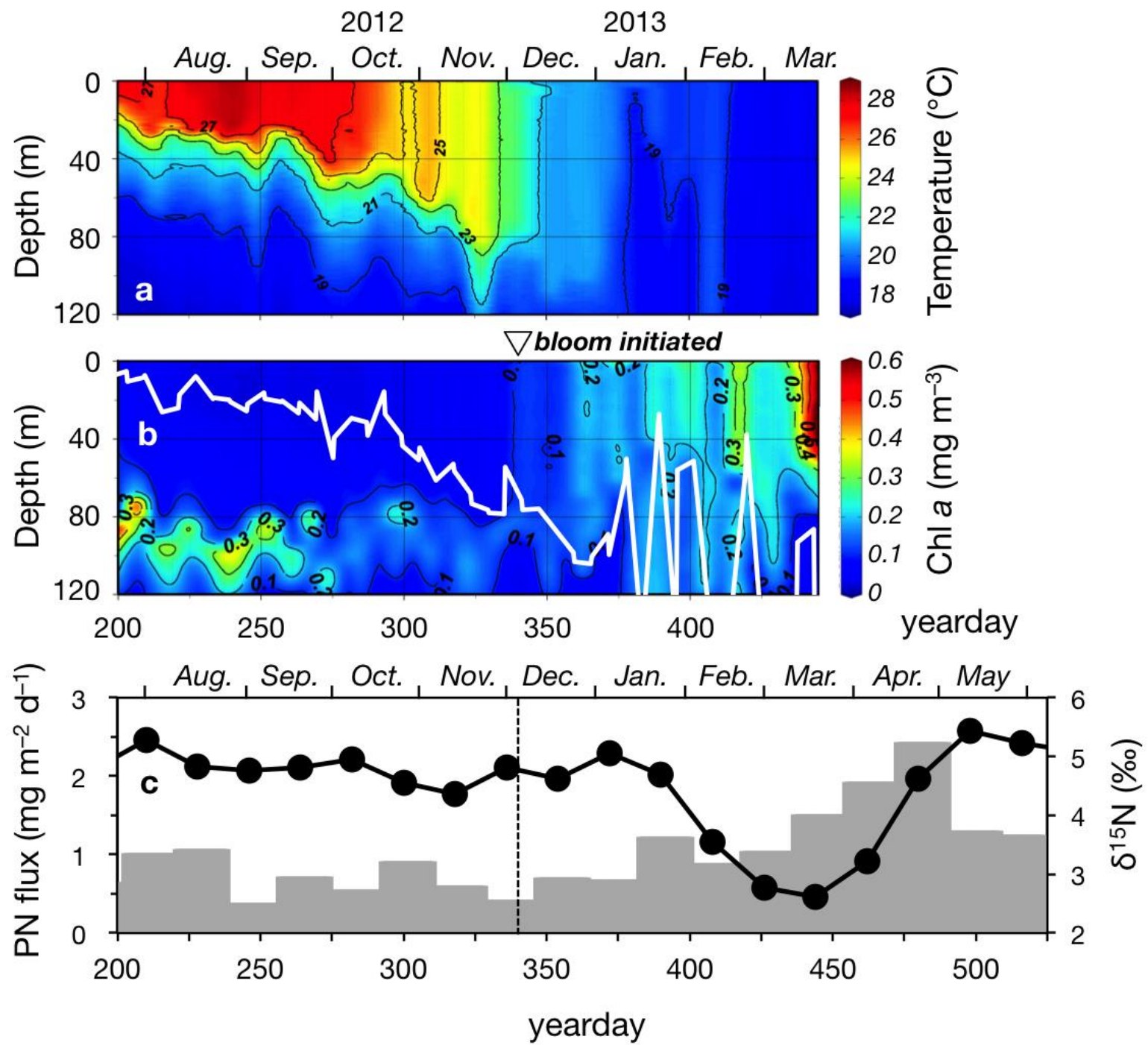

Figure 8. Time series of (a) temperature and (b) chlorophyll $a$ in S1 during July 2012 to March 2013 (yearday 200-445), obtained from underwater profiling buoy system. (c) particulate nitrogen flux (bars) and trapped $\mathrm{PN}-\delta^{15} \mathrm{~N}$ (circles) that were presented in Figure 5, but during July 2012 to June 2013 (yearday 200-540). The white line in panel b indicates the mixed layer depth. An inverted triangle indicates when the upper Chl $a$ concentration becomes $>0.10 \mathrm{mg}$ $\mathrm{m}^{-3}$ around yearday 340 (5 December 2012), which agrees well with the bloom initiation timing listed in Table 2. This timing is indicated as a dashed line in panel c. "yearday" is defined as the number of days since 1st January 2012 (yearday 1). 


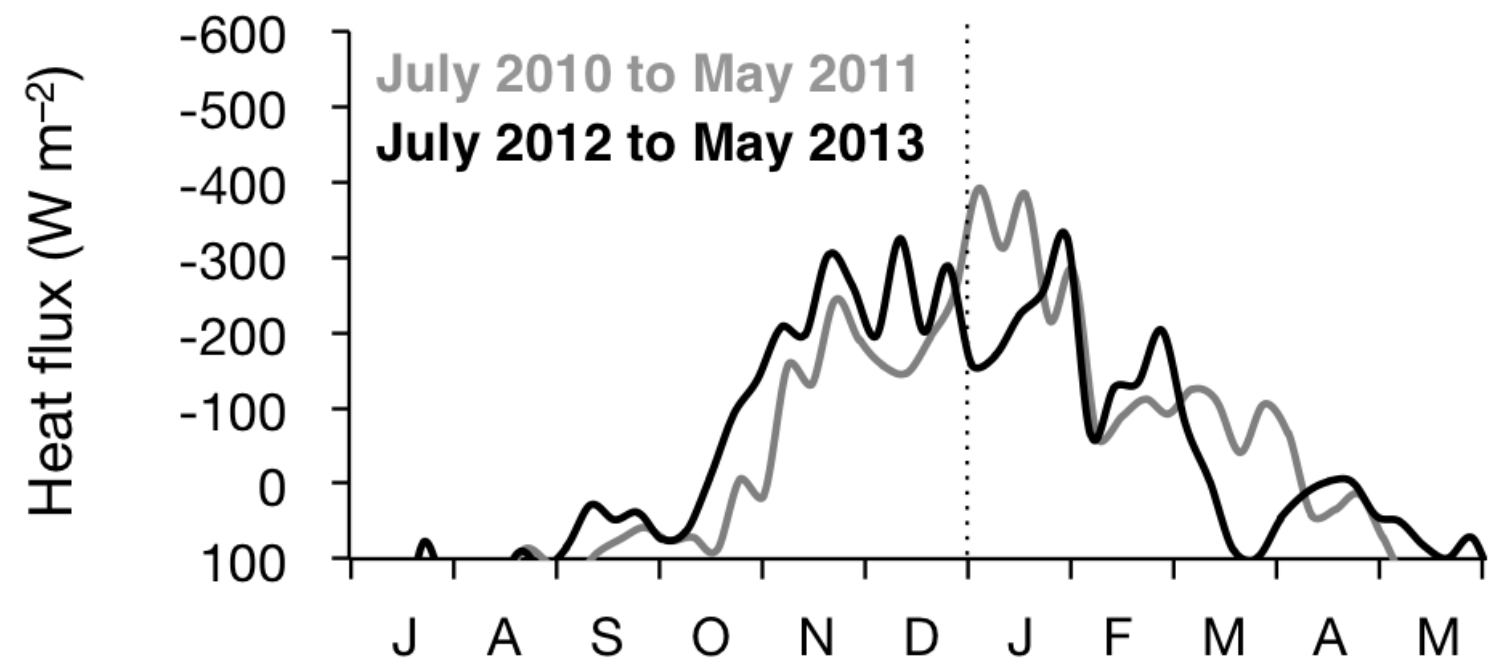

Figure 9. Time series of weekly air-sea net heat flux during July 2010-May 2011 (black line) and July 2012-May 2013 (gray line) at S1. These data were obtained from the objectively analyzed data set in the WHOI OAFlux Project. Vertical dotted line indicates when the year begins. 